【論 文】

UDC : 624. $02: 624.042 .7: 620.1$

\title{
新耐震設計法ならびに地震時塑性層間変位を考慮した 鉄筋コンクリート骨組の最適設計
}

\section{1. 序}

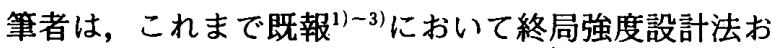
よび弾性解析結果に基づく静的ならびに動的な荷重を受 ける鉄筋コンクリート（以下 RC と略記）骨組の最適 設計法について報告した。しかし，わが国で常用の新耐 震設計法および日本建築学会 $\mathrm{RC}$ 構造計算規準 ${ }^{4}$ に準拠 する $\mathrm{RC}$ 骨組の最適設計法については未検討であった。 最適設計の役割の一つは, 所定の設計条件のもとに最適 設計された骨組の特徴およびその力学的性能を明らかに することにより，より適切な設計方法の建設を図るとこ ろにある。

そのため, 本研究ではまず現行の日本建築学会 RC 構造計算規準に基づく $\mathrm{RC}$ 骨組の最適設計法を提示し, かつこの手法を適用した解析例を通して設計解の特徵を 明らかにするとともに, 水平力作用時の単調載荷弾塑性 解析および大地震時を想定した実地震波による弾塑性地 震応答解析により設計骨組の力学的性能ならびにその特 長および欠点を論じることとした。

ところで現行の RC 設計規準によって最適設計した 骨組は，骨組およびその構成部材の強度的条件および弾 性変形条件は満足していても大地震時の骨組の塑性変形 まで考虑すると骨組の剛性が不足することが考えられ る。このため，本研究ではこのような場合に対応する設 計法として，大地震時における骨組の塑性層間変位の最 大值分布を指定した許容值に等しくするために必要な弾 性層剛性分布を求める設計法をこれまで示した最適設計 理論 ${ }^{2)}$ 用いて行う方法を提案する。

なお，地震時の応答変位を制御する最適設計法につい ては，鋼構造に関してはすでに中村ら ${ }^{51,61}$ により示され ている。しかし，これらの研究はいずれも弾性応答また は弾性骨組に対する設計法であり，本論で示すような骨 組の塑性変位応答については考慮されていない。また $\mathrm{RC}$ 構造に関しては塑性変位応答スペクトルを用いて応 答変位を算定し，これを設計に組み込んだZagajeski ら の研究7以外は今のところ見うけられない。

\section{2. 設計方針}

\footnotetext{
* 名古屋大学 助手・工修
}

(昭和 62 年 1 月 12 日原稿受理)

$$
\text { 正会員今 井信宏* }
$$

現行の設計規準に準拠する最適設計は，1 次設計およ び 2 次設計より成り，1 次設計では許容応力度設計法に 基づく骨組の最小重量設計を行う。1 次設計解は, 部材 の断面設計を許容応力度設計法で行う以外は, 全体骨組 の最適解を精度よく推定する既報 ${ }^{2} に$ 示した設計法をそ のまま用いて求める。2 次設計では, 保有水平耐力条件 および本研究で新たに設定した骨組の節点における降伏 形をはり降伏形とする条件により 1 次設計解の検定を行 い，満足しない場合は断面変更を行う。

次いで上記の方法により設計した骨組について，大地 震時塑性層間変位の最大值分布を次に示す方法により推 定し, 推定値が指定した許容値より大なる場合は, 塑性 層間変位が許容值と等しくなるに必要な弾性層剛性分布 を求め，この分布に基づいて部材断面の変更を行う。こ れは，現行の設計規準により最適設計した骨組について の実地震波を用いた大地震時を想定した弾塑性応答解析 の結果, いくつかの地震波に対して骨組の塑性層間変位 の最大值がかなり大きくなり骨組の勒性確保が困難とな ることがあるため用いる方法である。地震時塑性層間変 位の最大值分布は, 系の復元力特性を Degrading Trilinear (以下 D-Tri と略記) 型とした時の国内外で記録 された計 64 波の実地震波に対する変位応答の最大値を 統計的に取り扱うことにより作成した塑性変位応答スぺ クトルおよびモーダルアナリシスならびに RMS 法を用 いて弾性応答より推定する。また, 必要弾性層剛性分布 は, 既報 ${ }^{2)}$ に示した層間変位制限を受ける $\mathrm{RC}$ 骨組の最 小重量設計理論を適用して求める。

図一1 は，以上示した設計法の論理フローチャートを 示したもので，個々の部分については後節で説明する。 解析例として 2 例の $\mathrm{RC}$ 骨組の設計例をそれぞれの設 計法について示し，その考察を行った。

\section{3. 新䩂零設計法による RC 骨組の最小重量設計}

3.1 設計骨組，設計変数および作用荷重

設計骨組は既報 ${ }^{21}$ 亡同様, 骨組の幾何学的形状が既知 の柱脚固定の中低層 RC 平面ラーメンとし, 各層のは りおよび柱断面形状はそれぞれ $b_{i} \times h_{b, i, j}(i=1, \cdots, N$, $j=1, \cdots, n)$ の矩形断面および $D_{j, i} \times D_{j, i}(j=1, \cdots$, $n+1)$ の正方形断面とする。ここに $N$ は層数， $n$ はス 

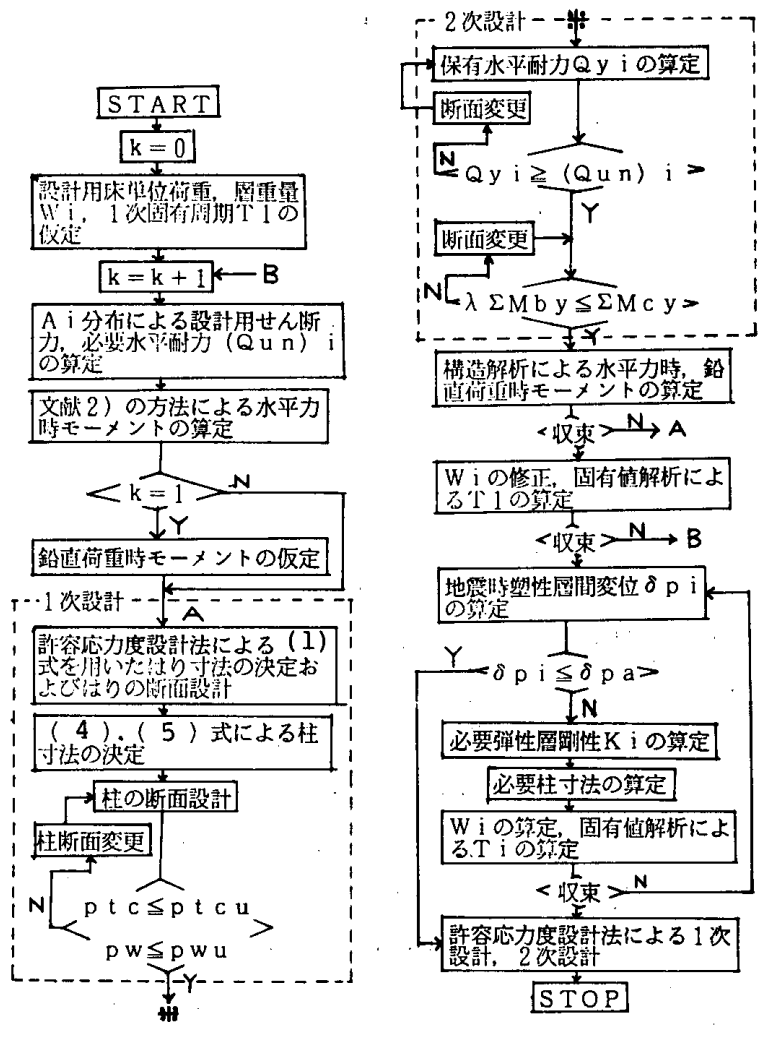

図一1 最適設計法の論理フローチャート

パン数，bははり幅でこれらは前もって指定する。

設計変数は, 骨組各層におけるはり全せい $h_{b, i,}$ およ び柱全せい $D_{J, i}$ とする。

1 次設計用層せん断力 $Q_{i}$ は， $A_{i}$ 分布に基づいて算定 し, その際, 地震地域係数 $Z$ および標準せん断力係数 $C_{0}$ の值を $Z=1.0, C_{0}=0.2$ とし, 振動特性係数 $R_{t}$ は 第二種地盤を想定して求める。2 次設計に用いる各層の 必要水平耐力 $Q_{u n}$ は, 構造特性係数 $D_{s}$, 形状係数 $F_{e s}$ および大地震時の設計用層せん断力 $Q_{u d}$ より求める。 ここでは, $D_{s}=0.3, F_{e s}=1.0$ とし， $Q_{u d}$ を求める際は, $C_{0}=1.0$ とした。

\section{2 制約条件および目的関数}

骨組各層および部材の各危険断面において適用した制 約条件式は次のようであるる

$$
\begin{aligned}
& 0.004 \leq P_{t b} \leq P_{t b u} \cdots \cdots \cdots \cdots \\
& 0.004 \leq P_{t c} \leq P_{t c u} \cdots \cdots \cdots \cdots \\
& 0.002 \leq P_{w} \leq P_{w u} \cdots \cdots \cdots \cdots \\
& D \geq D_{\min } \cdots \cdots \cdots \cdots \cdots \cdots \cdots \\
& \delta_{i} \leq \delta_{a} \quad(i=1, \cdots, N) \cdots \cdots \\
& Q_{y t} \geq\left(Q_{u n}\right)_{t} \quad(i=1, \cdots, N) \\
& \lambda \sum M_{b y} \leq \sum M_{c y} \cdots \cdots \cdots \cdots \cdots
\end{aligned}
$$

ここに $P_{t b}, P_{t c}, P_{w}$ ：はりおよび柱主筋引張鉄筋比な らびに帯筋比， $D_{\min }$ : 指定した最小柱せい, $\delta_{i}: i$ 層弾 性層間変位, $\delta_{a}$ : 指定した許容弾性層間変位, $Q_{y i}: i$ 層保有水平耐力, $\Sigma M_{b y}, \Sigma M_{c y}$ : 節点におけるはりおよ び柱の降伏モーメントの和, $\lambda$ ：柱降伏モーメントの和
のはり降伏モーメントの和に対する割增係数, $u$ : 上限 を示す添字

ここで， $P_{t b}$ および $P_{t c}$ は，はりおよび柱引張鉄笳断 面積をそれぞれ部材の有効断面積 $(b d),\left(D^{2}\right)$ で除して 求める。ここに $d$ ははり有効せいである。なお， (2) 式の柱鉄筋比の最小值は RC 規準では主筋断面積の合 計が柱全断面積の $0.8 \%$ 以上あることとなっているが, 本研究では片側引張部分の引張鉄筋比を $0.4 \%$ 以上之 する制約条件とした。また，（7）式は本研究で新たに 設定した制約条件で，最上階の一部および最下階柱脚部 の節点を除く骨組各節点での降伏形をはり降伏形とする 制約条件である。柱降伏モーメント割増係数 $\lambda$ の値と してはこれまで1.3〜2.0程度の值が示されている

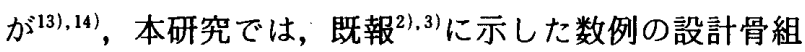
についての単調載荷弾塑性解析を試行錯誤的に行ったと ころ $\lambda=1.2$ 以上であればほぼはり降伏形の骨組として 設計できることが判明したため, 小さい方の値をとって $\lambda=1.2$ とした。

目的関数 $F$ は, 次に示す各層のはりお゙よび柱重量 $W_{b l}, W_{c t}$ の総和とし, RC 部材の比重 $\rho$ は普通コンク リートを想定して $\rho=2.4$ とした。

$$
F=\rho \sum_{i=1}^{N}\left(W_{b i}+W_{c i}\right)
$$

なお，はりおよび柱の鉄筋量は，はりおよび柱部材寸 法の従属変数として取り扱う”。

\section{3 設計の概要}

1 次設計では, (1)〜（５) 式の制約条件のもとに（8) 式を最小にするはりおよび柱せいを次のように求める。 まず，既報2りに示した層間変位制限を受ける RC 骨組の 最小重量設計解より得られる水平力時モーメント, 軸力 分布および別に求めた鉛直荷重時のそれより設計用モ一 メント，軸力分布を定める。次に既報 ${ }^{2} 2.4$ 節に示した 断面設計法によりこれらの分布に対してはりおよび柱重 量を最小にする必要最小はり，柱せいを求める。ただし， 断面設計は $\mathrm{RC}$ 規準 ${ }^{4}$ に示される許容応力度算定式を用 いて行う。これら算定式の表示は字数の関係上ここでは 揭げない。詳しくは文献4）を参照されたい。この断面 設計において許容応力に関する制約条件も設計に課せら れることになるが，これらの制約は既報”にに示したよう に必要最小部材せいを求める過程においてすべて（1） （（3）式に示した $P_{t b}, P_{t c}, P_{w}$ に関する制約条件に置 き換えられて考慮される。

2 次設計では, 1 次設計解について (6)，（7）式の 検定を行い，満足しなければ後述の $3.5,3.6$ 節に示す 方法によりはりおよび柱重量の増分が最小になるよう断 面変更を行う。

新耐震設計法で定められている剛性率および偏心率の 検討は，これらはいずれも満足されているものとしてこ 
こでは取り扱わない。最終的な設計解はこれらの手順を 収束するまで繰り返すことにより求め,一つの綝り返し ステップの間は, 骨組の層重量および設計用 1 次固有周 期 $T_{1}$ は固定する。また，図一1に示した収束判定基準 は設計変数を $x$ として次式を用いた。

$$
\left|x^{s}-x^{s-1}\right|<\varepsilon
$$

ここに $s$ : 計算ステップ番号, $, \varepsilon:$ 適当な正の数

\section{$3: 4$ 保有水平耐力 $Q_{y t}$ の算定}

保有水平耐力の算定には節点モーメント振分法を用い る15)。骨組のは,りおよび柱端危険断面における降伏モ一 メント $\boldsymbol{M}_{b y}, \boldsymbol{M}_{c \boldsymbol{y}}$ は次式により求める4)。

$$
\begin{aligned}
& M_{b y}=0.9 P_{t b} f_{y} b d^{2} \\
& M_{c y}=0.8 P_{t c} f_{y} D^{3}+0.5 N_{c} D\left(1-N_{c} / F_{c} D^{2}\right)
\end{aligned}
$$

ここに $f_{y}$ ：主筋降伏点強度, $F_{c}$ : コンクリート設計 基準強度, $N_{c}$ : 短期荷重時柱軸力

$i$ 層保有水平耐力 $Q_{y l}$ は, $M_{b y} ; M_{c y}$ を節点における $M_{b y}^{\prime}, M_{c y}^{\prime}$ に換算した後，節点における降伏形を決定し， 降伏形に応じて上下の柱に分配された節点モーメントの 值から決定される各柱のせん断力の和として求める。こ の時, はり降伏形の節点におけるはりモーメントの総和 の上下の柱への分配率は次のように定めた。設計用水平 力が作用した場合の各層の柱の反曲点高さを一般階につ いては下から $(0.5 h, 0.5 h)$, 最下階 $(0.6 h, 0.4 h)$ とし，この值の比に応じて柱への分配率 $D_{v}$ を定める。 この反曲点高さは，1 次設計解に設計用水平力が作用し た場合の弾性数値計算例の結果を参考にして定めた略算 值である。節点はり降伏形の場合の上下の柱への分配率 $D_{v 上}$ (柱頭)， $D_{\text {V下 }}$ (柱脚) は次式となる。

$$
\begin{array}{r}
D_{v \pm, l}=Q_{i} h_{t} /\left(Q_{\imath} h_{i}+Q_{i+1} h_{i+1}\right) \quad(i=2, \cdots, N-1) \\
\cdots \cdots \cdots \cdots \cdots \cdots \cdots \cdots \cdots \cdots(11 \cdot \mathrm{a}) \\
D_{v \pm, 1}=0.4 Q_{1} h_{1} /\left(0.4 Q_{1} h_{1}+0.5 Q_{2} h_{2}\right) \cdots(11 \cdot \mathrm{b}) \\
D_{V \leftarrow, i}=1-D_{v 上, i-1} \quad(i=2, \cdots, N) \cdots \cdots \cdots \cdots(11 \cdot \mathrm{c})
\end{array}
$$

ここに $Q_{l}: i$ 層 1 次設計用層せん断力, $h_{i}: i$ 層階高

3.5 保有水平耐力制約条件を犯した場合の改善方法 保有水平耐力が不足した場合は，一般階については， 節点降伏形がはり降伏形であることより, 当該層の上下 に連らなるはり（それぞれ上より，下はりと呼ぶ）の端 部の降伏モーメントを増加させることにより, 最下階に ついては，上はり端部および柱脚部の降伏モーメントを
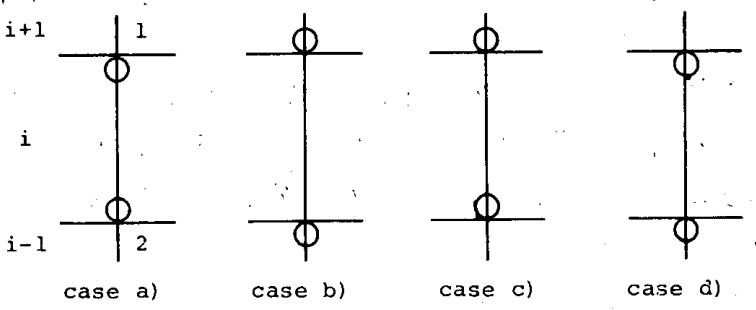

case a)
増加させることにより解を改善する。

保有水平耐力の不足分を $\Delta Q$, 上はりおよび下はり端 部における降伏モーメントの増分 $\Delta M_{b y, 上 ，} \Delta M_{b y, \text { 下 }}$ の総

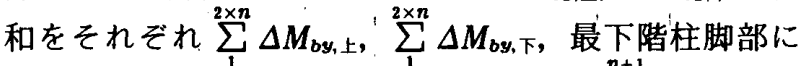
おけるモーメントの増分 $\Delta M_{c y}$ の総和を $\sum_{-1}^{n+1} \Delta M_{c y}$ とし て改修手順を示すと次のようになる。

一般階では， $\sum \Delta M_{b y, 上}$ と $\Sigma \Delta M_{b y, 下}$ の比を次式で定め る。

$$
\begin{aligned}
& \sum \Delta M_{b y, \pm, l}: \sum \Delta M_{b y, 下, l}=\left(Q_{\imath} h_{t}+Q_{t+1} h_{t+1}\right) \\
& :\left(Q_{i} h_{i}+Q_{i-1} h_{i-1}\right) \quad(i=3, \cdots, N) \cdots \cdots(12 \cdot a) \\
& \sum \Delta M_{b y, \pm, l}: \sum \Delta M_{b y, \text { 下 }, l}=0.5\left(Q_{t} h_{t}+Q_{t+1} h_{t+1}\right) \\
& :\left(0.5 Q_{t} h_{t}+0.4 Q_{t-1} h_{t-1}\right) \quad(i=2) \cdots \cdot(12 \cdot \mathrm{b})
\end{aligned}
$$

また, $i$ 層におけるモーメントのつり合いより次式が 得られる。

$$
\sum \Delta M_{b y_{1, t}, D_{v 上, t}}+\sum \Delta M_{b y, \mathrm{~T}, t} D_{\mathrm{V下}, t}=\Delta Q_{t} h_{t}
$$

(12)，(13）式より次式が得られる。

$$
\begin{aligned}
& \sum \Delta M_{b y, \pm, l}=\Delta Q_{i} h_{t} /\left(2 D_{v 上, t}\right) \quad(i=2, \cdots, N) \\
& \sum \Delta M_{b y, \mathrm{~F}, l}=\Delta Q_{\iota} h_{\iota} /\left(2 D_{V \mathrm{~F}, l}\right) \quad(i=2, \cdots, N)
\end{aligned}
$$

同様にして最下階でも次式が得られる。

$$
\begin{aligned}
& \sum \Delta M_{b y, t, 1}=0.4 \Delta Q_{1} h_{1} / D_{v+, 1} \cdots \cdots \cdots \cdots \cdots \cdots(15 \cdot a) \\
& \sum \Delta M_{c y}=0.6 \Delta Q_{1} h_{1}
\end{aligned}
$$

ところで， $i$ 層はりに分配する降伏モーメントの增分 の総和 $\Sigma \Delta M_{b y, i}$ として,$i$ 層上はりモーメントおよび 直上階下はりモーメントの増分の 2 個の増分量が存在す るため，図一2に示す 4 つのパターンを考え，次の手順 により $\Sigma \Delta M_{b y, i}$ を求めた。図中に示した○印は，上は りおよび下はりの増分量のうち，ビららが大きいかを示 す指標で例えば，Case a) の節点 1 において○印が下 にあれば， $i$ 層上はりモーメントの増分量 $\Sigma \Delta M_{b y, \pm, l}$ に より， $i$ 層はりへの分配モーメントの総和 $\Sigma \Delta M_{b y, i}$ が 定まることを示す。

Case a) および Case b) の場合は，上はりおよび下 はりモーメント増分のうち大きい方を $\Sigma \Delta M_{b y, i}$ として $Q_{y i}$ を改善する。したがって, Case b)，の場合は, 改善 $Q_{y_{i}}$ は必ず $\left(Q_{u n}\right)_{t}$ を上回ることになる。

Case c) の場合は $\Sigma \Delta M_{b y, i}=\sum \Delta M_{b y, \text { 下, } l+1}=\sum \Delta M_{b y, \perp, i}$ とおき，これを（13）式に代入して $i$ 層下はりモーメン 卜の増分量 $\Sigma \Delta M_{b y, \text { 下, } l}$ を $\left(\Sigma \Delta M_{b y, 下, l}\right)^{\prime}$ に減少させた後, 次式により. $(i-1)$ 層のはりモーメントの增分量を求め る。

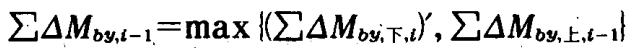

Case d) の場合は, Case c) の場合の逆のことを行う。

こうして定めた $\Sigma \Delta M_{b y, i}$ および $\Sigma \Delta M_{c y, i}$ をそれぞれ の材端部に分配する。 $\Sigma \Delta M_{b y, i}$ のはり端部への分配は, 
簡単のためそれぞれの端部での增分量が等しくなるよう に, 最下階柱脚部への $\Sigma \Delta M_{c y, 1}$ の分配は, 内柱の分配 率：外柱の分配率 $=2: 1$ となるよう分配する。はり端 部および内柱柱脚, 外柱柱脚部への降伏モーメントの増

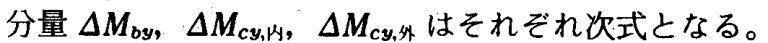

$$
\begin{aligned}
& \Delta M_{b y}=\sum \Delta M_{b y}(1-D / l) /(2 n) \cdots \\
& \Delta M_{c y, k y}=2 \Delta M_{c y, 4 k}=\sum \Delta M_{c y} / n
\end{aligned}
$$

ここに $l$ : スパン長, $n:$ スパン数

次に，この降伏モーメントの増分に対してはりおよび 柱重量の増分が最小となるよう，はりおよび柱端部の引 張鉄筋量を增加させることにより解を改善する。

降伏モーメントの増加に伴うはりおよび柱引張鉄筋比 の增分 $\Delta P_{t b}, \Delta P_{t c}$ は, 重量変化による影響を無視する と次式となる。

$$
\begin{aligned}
& \Delta P_{t b}=\Delta M_{b y} /\left(0.9 f_{y} b d^{2}\right) \\
& \Delta P_{t c}=\Delta M_{c y} /\left(0.8 f_{y} D^{3}\right) \cdots
\end{aligned}
$$

なお, 修正された $P_{t b}, P_{t c}$ が限界値 $P_{t b u}, P_{t c u}$ を超 える場合は，修正された材端部降伏モーメント $M_{b y}$, $M_{c y}$ を用いて (10) 式において $P_{t b}=P_{t b u}$ あるいは $P_{t c}$ $=P_{t c u}$ とおいて (10) 式を満足するはりおよび柱寸法 に断面を変更する。

3.6 節点はり降伏形条件を犯した場合の改善方法

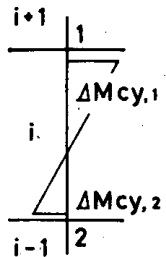

この場合は，節点の上下 の層の柱降伏モーメント $\boldsymbol{M}_{c y}$ の值を(11)式に示した 分配率 $D_{v}$ の比に応じて増 加させることにより解を改 善する。 $i$ 層柱の降伏モーメ

图一3 柱モーメントの増分 ントの増分 $\Delta M_{c y, t}$ は次式に より求める(図一 3 参照)。

$$
\Delta M_{c y, i}=\max \left(\Delta M_{c y 1}, \Delta M_{c y 2}\right)
$$

柱頭および柱脚におけるモーメントの增分 $\Delta M_{c y 1}$, $\Delta M_{c y 2}$ は次式による。

$$
\begin{aligned}
& \Delta M_{c y 1}=\lambda \Sigma M_{b y}-M_{c y, i+1} \\
& \Delta M_{c y 2}=D_{\sqrt{\top}, i}\left\{\lambda \sum M_{b y}-\left(M_{c y, i}+M_{c y, i-1}\right)\right\}
\end{aligned}
$$

この手順は上層より下層に向って行う。柱断面を変更 する場合の方法は, 3.5 と同様である。

\section{7 解析例およびその考察}

以上示した設計法による 5 層 3 スパン (Case 1) お よび 3 層 3 スパン (case 2) RC 骨組の 2 例の最小重量 設計例を通して，設計解の特徵を明らかにする。

設計に用いた骨組の形状および設計変数を図一4に， 架構モデルを図一5に示す。ただし，設計変数について は設計骨組が等スパン骨組であるため $h_{b t}=h_{b, i, J}, D_{i}=$ $D_{J, i}$ としてある ${ }^{2)}$ 。”設計用床単位荷重の值は，常時 560 $\mathrm{kgf} / \mathrm{m}^{2}$, 地震時 $460 \mathrm{kgf} / \mathrm{m}^{2}$ とし図一 5 に示す斜線部に 作用するものとする。ただし，この値は，はり自重を除

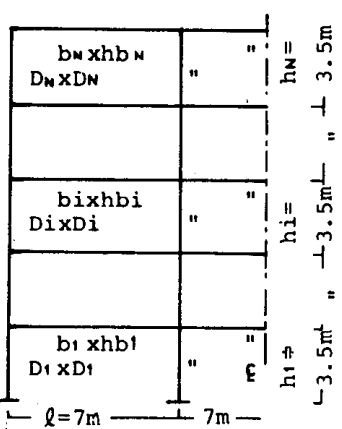

图一４，骨組の形状および設計変数

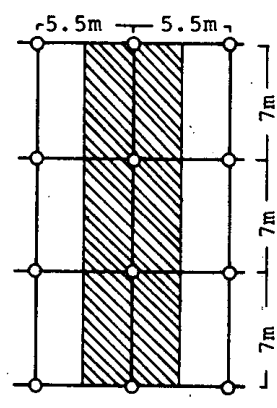

図一5架構モデル
いた值である。これらの値は図一1に示した繰り返し計 算の間にはり自重を加えた値に修正される。表一1に前 もって与えた諸量のうち， $F_{c} ， f_{y}$ ，世ん断補強筋降伏 点強度 ${ }_{w} f_{y}, P_{t b u}, P_{t c u}, P_{w u}, \lambda$ および $\delta_{a}$ の值を示す。 解析においては，（9）式の収束判定基準に用いた $\varepsilon$ の 值は $\varepsilon=0.5 \mathrm{~cm}$ とし, $D_{\min }=l / 15$ とした。また部材の 断面設計ではヤング係数比 $n$ は $n=15$, 鉄筋かぶり厚 は全せいの $1 / 10$ ，はりの断面設計における複筋比を $\gamma$ $=0.5$ とした。図一1に示す解析の最初のステップにお いて仮定した $T_{1}$ の値は， $T_{1}=0.02 h$ ( $h$ は建物全高さ $)$ より求めた。

表一 2 ，表一 3 に Case 1, Case 2 それぞれの場合につ いての部材寸法 $h_{b} ， D$, 設計用層せん断力 $Q$ および保 有水平耐力 $Q_{y}$ の值を 1 次設計解および 2 次設計解につ いて示す。図一6, 図一-8に 2 次設計解に対する $P_{t b}, P_{t c}$, $P_{w}$ の值を, 図一7, 図一-9に左側より載荷した場合のは り，柱降伏モーメントの値を示す。なお，図一7，図一9 において節点に付した○印は，節点はり降伏形条件が効

\begin{tabular}{|c|c|c|c|c|c|c|c|c|c|c|}
\hline \multirow{2}{*}{$\begin{array}{l}\text { story } \\
\text { No. }\end{array}$} & \multicolumn{5}{|c|}{ lst Design } & \multicolumn{5}{|c|}{ 2nd Design } \\
\hline & 1 & 2 & 3 & 4 & 5 & 1 & 2 & 3 & 4 & 5 \\
\hline$b(\mathrm{~cm})$ & 40.0 & 35.0 & 35.0 & 30.0 & 30.0 & 40.0 & 35.0 & 35.0 & 30.0 & 30.0 \\
\hline $\mathrm{hb}(\mathrm{cm})$ & 73.1 & 75.6 & 68.4 & 63.6 & 56.0 & 79.9 & 84.4 & 76.3 & 70.1 & 56.0 \\
\hline D $(\mathrm{cm})$ & 54.6 & 52.9 & 49.3 & 46.7 & 46.7 & 55.0 & 54.3 & 50.7 & 50.1 & 46.7 \\
\hline$Q(t f)$ & 74.7 & 67.4 & 56.9 & 43.3 & 26.5 & 112.2 & 101.2 & 85.5 & 65.3 & 39.7 \\
\hline$Q y(t f)$ & 101.5 & 77.4 & 63.4 & 48.8 & 33.2 & 112.2 & 101.2 & 85.5 & 65.3 & 44.6 \\
\hline
\end{tabular}
いている節点を示す。

最終的な骨組部材断面寸法および鉄筋量は，最上階は りせいが 1 次設計で決定されるのを除いてすべて 2 次設 計により決定し，保有水平耐力および節点はり降伏形条

\begin{tabular}{l|c|c|c|c|c|c|c}
\multicolumn{2}{c}{ 表一1 前もって与えた諸量 } \\
\hline $\begin{array}{c}\text { Fc } \\
\left(\mathrm{kgf} / \mathrm{cm}^{2}\right)\end{array}$ & $\begin{array}{c}\mathrm{fy} \\
\left(\mathrm{kgf} / \mathrm{cm}^{2}\right)\end{array}$ & $\begin{array}{c}\text { wfy } \\
\left(\mathrm{kgf} / \mathrm{cm}^{2}\right)\end{array}$ & $\begin{array}{l}\text { ptbu } \\
(\mathrm{g})\end{array}$ & $\begin{array}{l}\text { ptcu } \\
(8)\end{array}$ & $\begin{array}{c}\text { pwu } \\
(8)\end{array}$ & $\lambda$ & $\delta \mathrm{a}$ \\
\hline 210 & 3000 & 2400 & 1.2 & 1.0 & 1.2 & 1.2 & $\mathrm{hi} / 200$ \\
\hline
\end{tabular}

表一2 部材寸法, $Q, Q_{y}$ の値 (Case 1)

表一3 部材寸法, $Q, Q_{y}$ の值（Case 2)

\begin{tabular}{c|ccc|ccc}
\hline \multirow{2}{*}{$\begin{array}{c}\text { story } \\
\text { No. }\end{array}$} & \multicolumn{3}{|c|}{ 1st Design } & \multicolumn{3}{c}{ 2nd Design } \\
\cline { 2 - 7 } & 1 & 2 & 3 & 1 & 2 & 3 \\
\hline $\mathrm{b}(\mathrm{cm})$ & 35.0 & 30.0 & 30.0 & 35.0 & 30.0 & 30.0 \\
$\mathrm{hb}(\mathrm{cm})$ & 61.1 & 60.3 & 55.9 & 65.3 & 64.3 & 55.9 \\
$\mathrm{D}(\mathrm{cm})$ & 46.7 & 46.7 & 46.7 & 46.7 & 46.7 & 46.7 \\
Q (tf) & 42.2 & 34.2 & 21.6 & 63.3 & 51.2 & 32.4 \\
QY(tf) & 53.8 & 42.3 & 30.7 & 63.3 & 51.2 & 38.0 \\
\hline
\end{tabular}




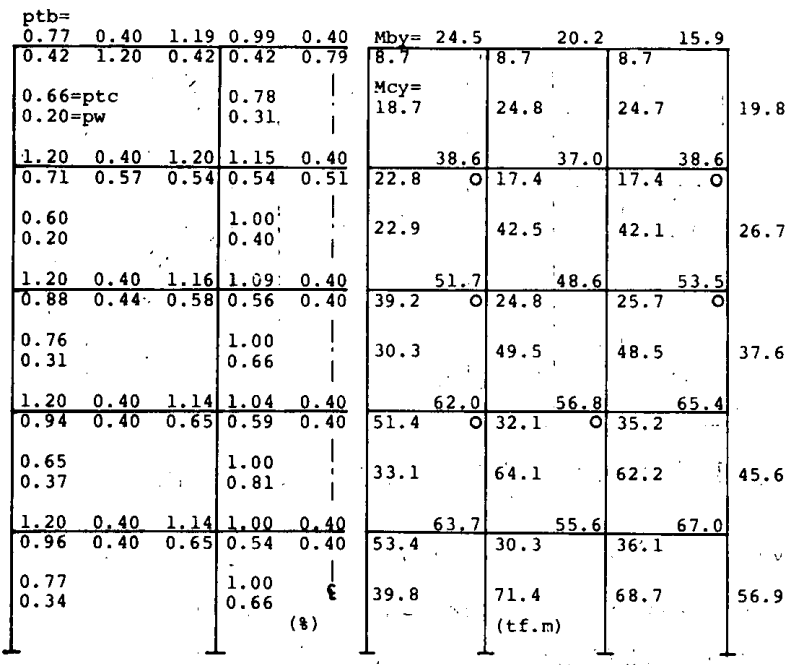

図一 $P_{t b}, P_{t c}, P_{w}$ の值 (Case 1)

図一7降伏モーメントの值 (Case 1)

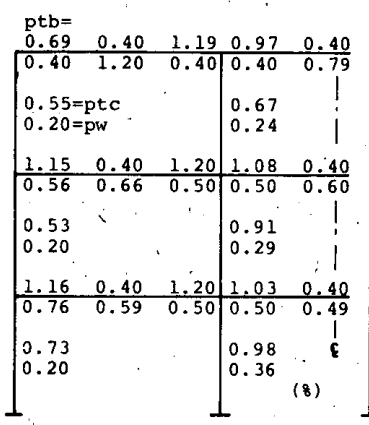

国一8 $P_{t b}, P_{t c}, P_{w}$ の値 (Case 2)

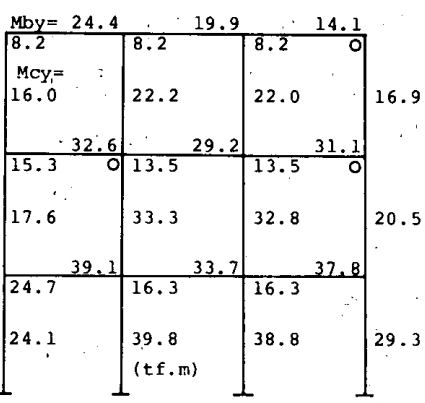

図一9.降伏モーメントの値

(Case 2)
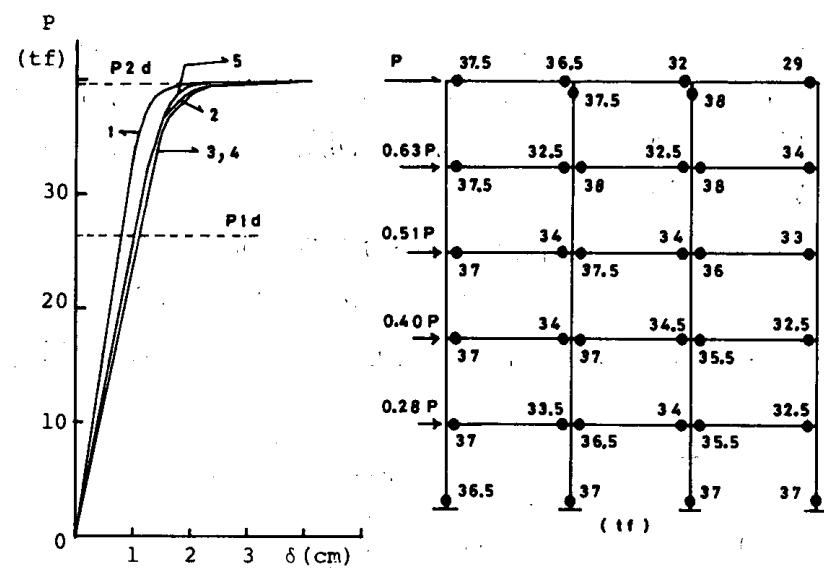

図一10 単調載荷弾塑性解析結果（Case 1)

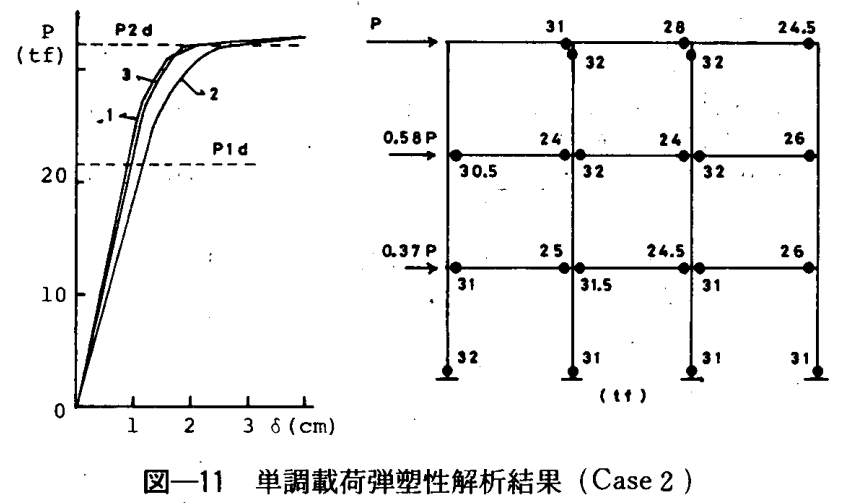

件が部材寸法決定に重要な役割を果している。これは, 表一 2 ，表一 3 にみられるように， 1 次設計解に対する $Q_{y i}$ の值が， 2 次設計に対する $\left(Q_{u n}\right)_{i}$ を下回るため保有 水平耐力の改善が行れ，その結果，はりについては，は り端部降伏モーメントの值が高められ結果的には限界は り引張鉄筋比条件により断面寸法が決定した。柱につい ては,一般階では, 保有水平耐力改善によるはり降伏モ一 メントの上昇に伴って, 節点はり降伏形条件を満すよう 柱降伏モーメシトの值が増加することにより柱寸法また は鉄筋量が決定し，限界柱引張鉄筋比を超える場合はこ れを満すよう柱寸法が決定される。最下階については, 節点はり降伏形条件が効いている節点がみうけられない ため，最下階の柱寸法は保有水平耐力条件により決定し たものと判断される。

次に設計解に対する力学的性能を, 設計用水平力分布 が作用した時の骨組の単調載荷弹塑性解析および大地震 時を想定した実地震波に対する弾塑性地震応答解析より 検討し，その特長および欠点を明らかにする。

図一10, 図一11に, Saafan-Argris ${ }^{16 !} ! の$ 方法による単 調載荷弾塑性解析結果を示す。図中には, 各層の水平力 $(P)$-層間変位 $(\delta)$ 関係および骨組崩壊時におけるはり, 柱端塑性ヒンジ発生位置わよび塑性ヒンジ発生時の $P$ の値を示した。なお，図中においての印は塑性ヒンジを， $P-\delta$ 図における数字は層番号を， $P_{1 d} ， P_{2 d}$ は 1 次およ び 2 次設計に対応す、る作用水平力をそれぞれ示す。

図一10，図一11より，両Case とも骨組は 2 次設計に より部材の剛性および鉄筋量が高められるため, 1 次設 計用水平力に対して骨組は弾性範囲にあり，1 次設計用 水平力の約 1.2 1.3 倍の水平力に対して各層の塑性化 が始まっている。また, 各層の保有水平耐力は 2 次設計 用水平力にほぼ等しくなっている。，層間変位の値は, 階 高の高いCase 1 の骨組では最下階を除いてその値がほ ぼ一様化しているのに対して, 階高の低い Case 2 の骨 組では， 2 層目にやや変形が集中する傾向がみられる。 塑性ヒンジの形成状態は，はり降伏形の骨組となってお り, 本研究で与えた柱降伏モーメント割増係数の值を入 $=1.2$ 程度とすれば，はり降伏形の骨組となることがわ かる。塑性ヒンジ発生状況は，各 Case ともまずスパン 風下側にヒンジが上層より下層に向って発生し, 次にス パン風上側および最下階柱脚部にヒンジが形成される。 Case 2 の骨組の 2 層目の塑性化が他の層に比べてやや 早い点を除くと，骨組はおおむね同時降伏形の骨組とし て設計されたといえる。

次に設計骨組の大地震時の応答性状を次章に示す 64 波の実地震波を地動の最大震度 $k_{g}=0.3$ （最大加速度 $294 \mathrm{gal})$ とした場合の弾塑性地震波応答解析より,検討 する。解析では骨組を曲げせん断系モデル（以下 SB モ デルと略記 $)^{171}$ に置換し, 中点加速度法により変位応答 
表一4 骨組の復元力特性, $W_{i}, Q_{1 d}, Q_{z d}, T$ の值 (Case 1)

\begin{tabular}{|c|c|c|c|c|c|c|c|}
\hline $\begin{array}{c}\text { story } \\
\text { No. }\end{array}$ & $\begin{array}{c}\delta \mathrm{c} \\
(\mathrm{cm})\end{array}$ & $\begin{array}{c}Q c \\
(t f)\end{array}$ & $\begin{array}{c}\delta y \\
(\mathrm{~cm})\end{array}$ & $\begin{array}{l}Q y \\
(t f)\end{array}$ & $\begin{array}{c}W i \\
(t f)\end{array}$ & $\begin{array}{l}Q 1 d \\
(t f)\end{array}$ & $\begin{array}{l}Q 2 d \\
(t f)\end{array}$ \\
\hline 1 & 0.39 & 49.3 & 3.03 & 112.2 & 79.4 & 74.7 & 112.2 \\
\hline 2 & 0.44 & 46.5 & 4.15 & 101.2 & 77.9 & 67.4 & 101.2 \\
\hline 3 & 0.45 & 38.4 & 4.25 & 85.5 & 75.2 & 56.9 & 85.5 \\
\hline 4 & 0.44 & 32.1 & 3.96 & 65.3 & 72.1 & 43.3 & 65.3 \\
\hline 5 & 0.42 & 21.0 & 3.58 & 44.6 & 68.9 & 26.5 & 39.7 \\
\hline
\end{tabular}

表-5 骨組の復元力特性, $W_{l}, Q_{1 d}, Q_{2 d}, T$ の値 (Case 2)

\begin{tabular}{|c|c|c|c|c|c|c|c|}
\hline $\begin{array}{l}\text { story } \\
\text { No. }\end{array}$ & $\begin{array}{c}\delta c \\
(\mathrm{~cm}) \\
\end{array}$ & $\begin{array}{c}Q C \\
\text { (tf) }\end{array}$ & $\begin{array}{c}\delta y \\
(\mathrm{~cm})\end{array}$ & $\begin{array}{c}Q y \\
(t f)\end{array}$ & $\begin{array}{c}\text { Wi } \\
\text { (tf) }\end{array}$ & $\begin{array}{l}\text { Q1d } \\
\text { (tf) }\end{array}$ & $\begin{array}{l}\text { Q2d } \\
\text { (tf) }\end{array}$ \\
\hline 1 & 0.45 & 28.8 & 3.33 & 63.3 & 72.0 & 42.2 & 63.3 \\
\hline 2 & 0.50 & 26.6 & 4.18 & 51.2 & 70.2 & 34.2 & 51.2 \\
\hline 3 & 0.40 & 18.4 & 3.17 & 38.0 & 68.9 & 21.6 & 32.4 \\
\hline
\end{tabular}

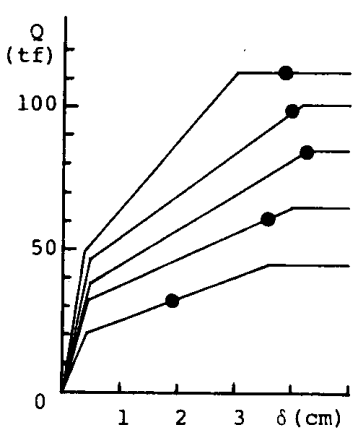

図一12 変位応答の最大値 (Case 1 )

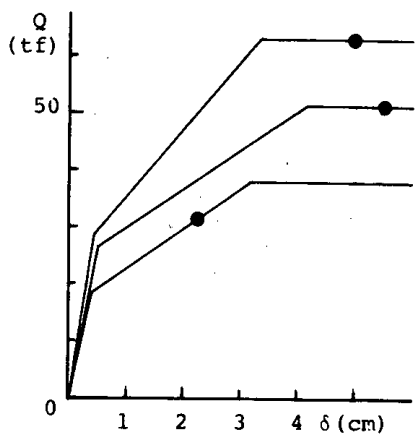

図一13 変位応答の最大值 (Case 2)
を求めた。その際は減衰は堿衰定数 $2 \%$ の内部減衰と し, SB モデルでのせん断バネの復元力特性を D-Tri 型, 曲げバネのそれは完全弾塑性型とした。表一4, 表一 5 に, 文献 18）に示されている方法により求めた各層の復元 力特性および層重量 $W_{i}$ および 1 次, 2 次設計用層せん 断力 $Q_{1 d}, Q_{2 d}$ ならびに弾性固有周期 $T$ の值をそれぞれ の Caseについて示す。図一12, 図一13 はこうして求め た 64 波の地震波に対する弹塑性変位応答の最大值を各 層のスケルトンカーブ上にプロットしたものである。変 位応答の最大值は, Case 1 では最上階のそれがスケル トンカーブの第 2 こう配上にあるのを除いて応答は各層 ほぼ降伏点近傍にありその値はほぼ一様化している。 Case 2 では 2 層目に変形が集中し, それに伴って 1 層 目の値も大きくなっており, 応答は降伏点をやや超えた 位置にある。この傾向は図一 10 , 図一11 に示した $P-\delta$ 関係にほぼ一致している。変位応答の最大值 $\delta_{\max }$ の値 は Case 1 で下層より $\left\{\delta_{\text {max }}\right\}^{T}=\{3.89,3.98,4.24,3.57$, $1.90\} \mathrm{cm}$, Case 2 で $\left|\delta_{\max }\right|^{T}=\{4.99,5.52,2.38\} \mathrm{cm}$ であ る。大地震時における許容層間変位の值を $h_{i} / 100$ 程度 とすれば，骨組は䩲性確保の面からみると層の剛性が不 足し，やや危うい設計となっているといえる。

これら大地震時の設計骨組の層剛性不足の要因は主と して, 設定した制約条件の上下限値により影響され，そ の意味ではこれらの値の設定にはより慎重な配慮が必要
ともみられる。しかし，大地震時の塑性変形を指定した 值以内に収めるためのこれら上下限値の適切な值をどの ようにして定めるかという問題になると，これらは互い に影響しあい，また作用荷重が異なれば結果も異なるこ とになり,これらの值を一概に定めることは困難である。 そのため, 本研究では問題を巨視的にとらえ，与えられ た制約条件は容認した上で, 大地震時塑性変形を指定し た値以内に収めるための首剛性分布を設計骨組の力学的 性質を加味して求めることとした。次章では，このよう な考え方をもとに大地震時における骨組の塑性層間変位 の最大值分布を制御する設計法について示す。

\section{4. 地霞時塑性層間变位の最大值分布を制御する RC 骨組の設計法}

ここでは，中低層 RC 骨組の地震時塑性層間変位を 弾性応答より推定する方法について示し, 次いでこの推 定法および既報 ${ }^{2} に$ に示した最適設計理論を用いて，地震 時塑性層間変位の最大值分布を一様化するに必要な弾性 層剛性分布を求める設計法について示す。

ところで RC 骨組の地震時塑性層間変位を推定する 方法はすでに文献 21）に示されているが,この方法に よる推定值と, 系の復元力特性を D-Tri 系とした場合 の前記 64 波の実地震波に対する変位応答の最大值分布 とを比較すると, 短周期の建物に対してその推定精度に やや問題がある。そのため, 本研究では変位応答の最大 值分布に着目して，64 波の実地震波に対する応答スペ クトル解析より弾性変位応答スペクトル $S_{D e}(T)$ を, D-Tri 応答に対して 1 質点系塑性変位応答スペクトル $S_{D p}(T)$ を新たに作成し，これらをもとに地震時塑性層 間変位を推定することとした。なお，以下に示す塑性層 間変位を推定する際には基本的な考え方を文献 9)，21） に示されている方法に採り，これらの方法を一部修正す ることにより解析を行った。

\section{1 地震時塑性層間変位 $\delta_{p t}$ の算定}

骨組各層の $\delta_{\rho t}$ は, D-Tri 型復元力特性に対して作成 した 1 質点系塑性変位応答スペクトル $S_{D p}(T)$ を用いて 次式のようにモーダルアナリシスおよび RMS 法より算 定する。

$$
\delta_{p i}=\sqrt{\sum_{k=1}^{f}\left(\beta_{k} S_{D p}\left(T_{k}\right)\left(\phi_{i}^{(k)}-\phi_{t-1}^{(k)}\right)\right)^{2}} \quad(i=1, \cdots, N)
$$

ここに, $\beta_{k}: k$ 次弾性刺激係数, $T_{k}: k$ 次弾性固有周” 期, $\phi_{i}^{(k)}: k$ 次弾性固有モード, $f:$ 考虑する次数

（21）式は， 3 章の解析例で示したように最適設計骨 組がほぼ同時降伏形の建物であること，および弾塑性変 位応答值の最大值が上層部を除いてほぼ降伏点近傍にあ り, 応答値之原点を結ぶ割線層剛性と弾性層剛性との比 が各層ほぼ同じであることより判断して, 塑性変形モー ドと弾性変形モードが比例すると仮定して求めた。この 
仮定の当否は後節 4.2.4 で検討する。

4.21 質点系塑性変位応答スペクトル $S_{D p}(T)$ の作成 $S_{D p}(T)$ は，次に示す国内外で記録された計 64 波の実 地震波に対する D-Tri 系弾塑性変位応答值を求め, こ れら応答値の最大値を包絡する曲線を別に求めた弾性変 位応答スペクトル $S_{D e}(T)$ より推定することにより求め る。

\subsection{1 入力地震波}

解析に用いた計 64 波の実地震波の一覧を表一6一表一 8 に示す。これらは，建物が建つ地盤種別を第二種地盤 と想定し，主として第二種地盤で記録された地震波を選 定した。表一6に示す地震波は国内の建物の基礎または 1 階床部分で記録された地震波 ${ }^{19)}$, 表一7 は国内の港湾 施設の地表面で記録された地震波 ${ }^{19}$, 表一8 はアメリカ

表一6 入力地震波 data (Structural data)

\begin{tabular}{|c|c|c|c|c|c|}
\hline No. & Place & Date & \multicolumn{3}{|c|}{$\begin{array}{l}\text { Component, Max.Acc. } \\
\text { (ga1), } \mathrm{TG} \text { (sec) }\end{array}$} \\
\hline 1 & $\begin{array}{l}\text { Earthquake Research Institute } \\
\text { Univ. of Tokyo }\end{array}$ & $56 / 2 / 14$ & $\begin{array}{l}\mathrm{NS} \\
\mathrm{EW}\end{array}$ & $\begin{array}{r}75.6 \\
57.8\end{array}$ & $\begin{array}{l}0.75 \\
0.85\end{array}$ \\
\hline 2 & $"$ & * & $\begin{array}{l}\text { NS } \\
\text { EW }\end{array}$ & $\begin{array}{l}69.1 \\
52.6\end{array}$ & $\begin{array}{l}0.78 \\
0.85\end{array}$ \\
\hline 3 & $\begin{array}{l}\text { Kushiro District Meteoro- } \\
\text { logical Observatory }\end{array}$ & $62 / 4 / 23$ & $\begin{array}{l}\text { NS } \\
\text { EW }\end{array}$ & $\begin{array}{l}281.5 \\
517.5\end{array}$ & $\begin{array}{l}0.28 \\
0.34\end{array}$ \\
\hline 4 & Tohoku Univ. & $62 / 4 / 30$ & $\begin{array}{l}\text { NS } \\
\text { EW }\end{array}$ & $\begin{array}{l}71.7 \\
51.7\end{array}$ & 0.86 \\
\hline 5 & " & $78 / 6 / 12$ & $\begin{array}{l}\text { NS } \\
\text { EW }\end{array}$ & $\begin{array}{l}258.0 \\
202.7\end{array} \mid$ & $\begin{array}{l}0.95 \\
0.95\end{array}$ \\
\hline 6 & $\begin{array}{l}\text { Public Works Research Insti- } \\
\text { tute,Chiba Branch, Chiba City }\end{array}$ & $63 / 8 / 4$ & $\begin{array}{l}\text { NS } \\
\text { EW }\end{array}$ & $\begin{array}{l}92.6 \\
79.2\end{array}$ & $\begin{array}{l}0.18 \\
0.19\end{array}$ \\
\hline 7 & $\begin{array}{l}\text { Tokai Power Station } \\
\text { Tokai Village }\end{array}$ & $63 / 5 / 8$ & $\begin{array}{l}\text { NS } \\
\text { EW }\end{array}$ & $\begin{array}{l}60.8 \\
64.9\end{array}$ & $\begin{array}{l}0.30 \\
0.35\end{array}$ \\
\hline 8 & $\begin{array}{l}\text { Meteorological Laboratory, } \\
\text { Tokai Village }\end{array}$ & $63 / 5 / 8$ & $\begin{array}{l}\text { NS } \\
\mathrm{E}\end{array}$ & $\begin{array}{l}29.5 \\
30.8\end{array}$ & 0.25 \\
\hline 9 & (1) & $64 / 2 / 5$ & $\begin{array}{l}\text { NS } \\
\text { EW }\end{array}$ & $\begin{array}{l}56.3 \\
39.7\end{array}$ & $\begin{array}{l}0.23 \\
0.20\end{array}$ \\
\hline 10 & " & $"$ & $\begin{array}{l}\text { NS } \\
\text { EW }\end{array}$ & $\begin{array}{l}202.9 \\
136.7\end{array} \mid$ & $\begin{array}{l}0.20 \\
0.20\end{array}$ \\
\hline 11 & " & " & $\begin{array}{l}\text { NS } \\
\text { EW }\end{array}$ & $\begin{array}{l}41.4 \\
31.7\end{array}$ & $\mid \begin{array}{l}0.29 \\
0.31\end{array}$ \\
\hline 12 & " & $64 / 11 / 14$ & $\begin{array}{l}\text { NS } \\
\text { EW }\end{array}$ & \begin{tabular}{|l|}
260.5 \\
238.3
\end{tabular} & $\begin{array}{l}0.17 \\
0.17\end{array}$ \\
\hline 13 & " & $67 / 11 / 19$ & $\begin{array}{l}\text { NS } \\
\text { EW }\end{array}$ & $\left|\begin{array}{l}464.3 \\
350.2\end{array}\right|$ & $\begin{array}{l}0.20 \\
0.23\end{array}$ \\
\hline 14 & " & $71 / 6 / 13$ & $\begin{array}{l}\text { NS } \\
\text { EW }\end{array}$ & $\begin{array}{l}248.1 \\
160.7\end{array}$ & $\begin{array}{l}0.22 \\
0.15\end{array}$ \\
\hline 15 & Hoshina & $66 / 4 / 5$ & $\begin{array}{l}\text { NS } \\
\text { EW }\end{array}$ & \begin{tabular}{|l|}
265.0 \\
499.4
\end{tabular} & $\begin{array}{l}0.26 \\
0.60\end{array}$ \\
\hline 16 & " & $66 / 4 / 17$ & $\begin{array}{l}\text { NS } \\
\text { EW }\end{array}$ & \begin{tabular}{|l|}
292.9 \\
118.8
\end{tabular} & $\begin{array}{l}0.22 \\
0.19\end{array}$ \\
\hline 17 & Wak aho & $66 / 4 / 5$ & $\begin{array}{l}\text { NS } \\
\text { EW }\end{array}$ & $\begin{array}{l}259.4 \\
268.3 \\
\end{array}$ & $\begin{array}{l}0.40 \\
0.36\end{array}$ \\
\hline
\end{tabular}

表一7 入力地震波 data (Harbour data)

\begin{tabular}{|c|c|c|c|c|c|}
\hline No. & Place & Date & \multicolumn{3}{|c|}{$\begin{array}{l}\text { Component, Max. Acc. } \\
\text { (ga 1) TG(sec) }\end{array}$} \\
\hline 1 & Central Wharf;Kushiro Harbour & $65 / 10 / 26$ & $\begin{array}{l}\text { NS } \\
\text { EW }\end{array}$ & $\begin{array}{r}105.6 \\
66.8\end{array}$ & $\begin{array}{l}0.25 \\
0.25\end{array}$ \\
\hline 2 & " & $68 / 8 / 7$ & $\begin{array}{l}\text { NS } \\
\text { EW }\end{array}$ & $\begin{array}{l}49.0 \\
86.0\end{array}$ & $\mid \begin{array}{l}0.36 \\
0.36\end{array}$ \\
\hline 3 & . & $71 / 8 / 2$ & $\begin{array}{l}\text { NS } \\
\text { EW }\end{array}$ & $\begin{array}{l}89.7 \\
76.1\end{array}$ & $\begin{array}{l}0.30 \\
0.32\end{array}$ \\
\hline 4 & " & $72 / 5 / 11$ & $\begin{array}{l}\text { NS } \\
\text { EW }\end{array}$ & $\begin{array}{r}142.8 \\
80.1\end{array}$ & $\begin{array}{l}0.32 \\
0.37\end{array}$ \\
\hline 5 & " & $72 / 6 / 17$ & $\begin{array}{l}\text { NS } \\
\text { EW }\end{array}$ & $\begin{array}{l}200.9 \\
126.8\end{array}$ & $\begin{array}{l}0.34 \\
0.35\end{array}$ \\
\hline 6 & $\begin{array}{l}\text { Muroran Harbour Construction } \\
\text { Office }\end{array}$ & $68 / 5 / 16$ & $\begin{array}{l}\text { NS } \\
\text { EW }\end{array}$ & $\begin{array}{l}221.5 \\
155.3\end{array}$ & 0.47 \\
\hline 7 & - & " & $\begin{array}{l}\text { NS } \\
\text { EW }\end{array}$ & $\begin{array}{r}113.8 \\
90.6\end{array}$ & $\mid \begin{array}{l}0.40 \\
0.46\end{array}$ \\
\hline 8 & Hachinohe Harbour Works office & $68 / 5 / 16$ & $\begin{array}{l}\text { NS } \\
\text { EW }\end{array}$ & $\begin{array}{l}311.7 \\
206.2\end{array}$ & $\begin{array}{l}0.85 \\
1.15\end{array}$ \\
\hline 9 & $\therefore$ & $74 / 7 / 8$ & $\begin{array}{l}\text { NS } \\
\text { EW }\end{array}$ & $\begin{array}{l}87.3 \\
84.4\end{array}$ & $\begin{array}{l}0.60 \\
0.64\end{array}$ \\
\hline 10. & Kashima Hạrbour Works office & $74 / 3 / 3$ & $\begin{array}{l}\text { NS } \\
\text { EW }\end{array}$ & $\begin{array}{r}37.7 \\
111.6\end{array}$ & $\begin{array}{l}0.65 \\
0.77\end{array}$ \\
\hline 11 & " & $74 / 11 / 16$ & $\begin{array}{l}\text { NS } \\
\text { EW }\end{array}$ & $\begin{array}{l}69.1 \\
91.4 \\
\end{array}$ & $\begin{array}{l}0.68 \\
0.75 \\
\end{array}$ \\
\hline
\end{tabular}

表一 8 入力地震波 data (USA data)

\begin{tabular}{|c|c|c|c|c|c|}
\hline No. & Place & Date & \multicolumn{3}{|c|}{$\begin{array}{l}\text { Component, Max.ACC } \\
\text { (qal), TG(sec) }\end{array}$} \\
\hline 1 & EI Centro, Calif., USA & $34 / 12 / 30$ & NS & & 0.37 \\
\hline 2 & $\cdots$ & $40 / 5 / 18$ & NS & 326.0 & 0.50 \\
\hline 3 & Olympia, wash., USA & $49 / 4 / 13$ & $\begin{array}{l}\text { NS } \\
\text { EW }\end{array}$ & $\begin{array}{l}184.2 \\
318.5\end{array}$ & $\begin{array}{l}0.38 \\
0.55\end{array}$ \\
\hline 4 & Taft, Calif., USA & $52 / 7 / 21$ & $\begin{array}{l}\text { NS } \\
\text { EW }\end{array}$ & $\begin{array}{l}174.4 \\
147.0 \\
\end{array}$ & $\begin{array}{l}0.69 \\
0.43 \\
\end{array}$ \\
\hline
\end{tabular}

で記録された地震波である。表中には，地震波の最大加 速度 $\max , A c c$, および $5 \%$ 減衰速度応答スペクトル およびパワースペクトル解析結果 ${ }^{20)}$ を参考にして求めた 地震波の特性周期 $T_{G}$ の値も併記した。

4.2.2 1 質点系弾性変位応答スペクトル $S_{D e}(T)$ の作 成

$S_{D e}(T)$ は次式に示す標準弾性速度応答スペクトル $S_{v e}(T)$ をもとに求める。 $S_{v e}(T)$ 作成の際は, 地動の最 大加速度を $1 \mathrm{~g}$ に拡大した前記 64 波の地震波を用いて 固有周期 $0.05 \sim 1.0$ 秒に対して求めた $5 \%$ 減衰 1 質点 系弾性速度応答侹の最大値分布および用いた地震波の特 性周期 $T_{G}$ が $0.15 \sim 1.15$ 秒と幅広く分布しその振動性 状が第二種地盤で記録された地震波にもかかからず第三 種地盤に属する特性周期を示す地震波もみうけられるこ とを考虑して，すでに示されている梅村による標準弾性 速度応答スペクトル式 ${ }^{18)}$ のち, 速度一定領域の速度応 答值を 1.2 倍した直線 ${ }^{21)}$ と速度応答が $T$ に比例する直 線とを結ぶことにより $S_{v e}(T)$ を求めた。

$$
\begin{aligned}
& S_{v e}(T)=565 T k_{g}[\mathrm{~cm} / \mathrm{sec}] \quad T \leq 0.6 \mathrm{sec} \text { の時 } \\
& =339 k_{g} \quad[\mathrm{~cm} / \mathrm{sec}] \quad T>0.6 \mathrm{sec} \text { の時 }
\end{aligned}
$$

(22) 式より $S_{\text {De }}(T)$ を求めると次式となる。

$$
\begin{aligned}
S_{D e}(T) & =90 T^{2} k_{g}[\mathrm{~cm}] & T \leq 0.6 \mathrm{sec} \text { の時 } \\
& =54 T k_{g} \quad[\mathrm{~cm}] & T>0.6 \mathrm{sec} \text { の時 }
\end{aligned}
$$

\section{ここに $k_{g}:$ 地動の最大震度}

図-14, 図-15 は, $5 \%$ 減衰, $k_{g}=1.0$ の場合の 64 波に対する応答值と $S_{V e}(T), S_{D e}(T)$ との関係を示した

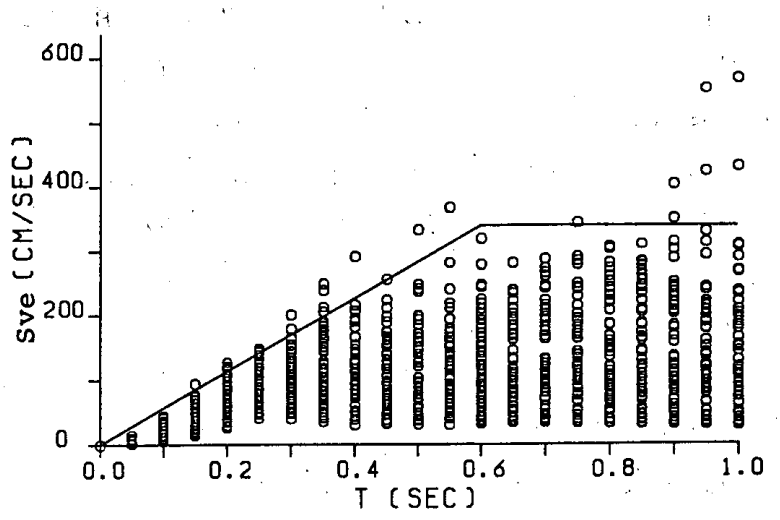

图一14 $S_{v e}(T)$ と弾性速度応答値との関係 $\left(k_{g}=1.0\right)$

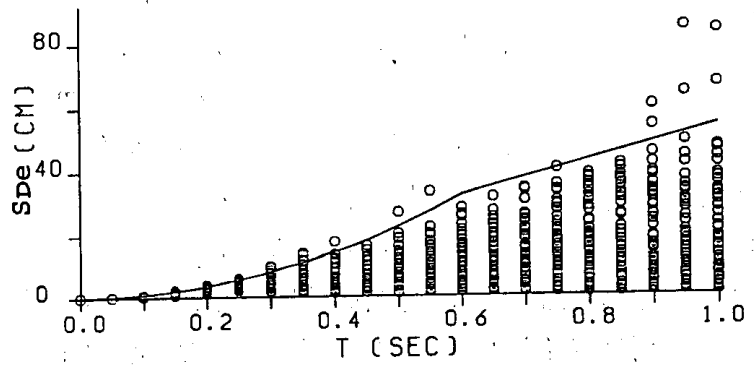

图-15 $S_{D e}(T)$ と弾性変位応答值との関係 $\left(k_{g}=1.0\right)$ 
もので, 速度応答については長周期でばらつきがみられ るが, 変位応答については $T<0.9$ 秒の場合はほぼ $(23)$ 式により変位応答値の最大值を包絡できることがわか る。

\subsubsection{D-Tri モデルを用いた応答スペクトル}

D-Tri モデルによる 64 波の実地震波に対する弾塑性 変位応答を求める際には，図一16に示すように系のひ び割れ震度を $k_{c}$, 降伏震度を $k_{y}$, 初期剛性を $K_{e}$, 降伏 点剛性低下率を $\alpha_{y}$, 初期および降伏点剛性に対する周 期を $T_{e}, T_{y}$ とする ${ }^{91}$ 。応答計算では，3章の解析例で示 した RC 骨組の復元力特性の結果より判断して $k_{c} / k_{y}=$ $1 / 2$ とし, $T_{y} / T_{e}=2$ および $T_{y} / T_{e}=\sqrt{2}$ の場合の各々 について $k_{y} / k_{g}=1.0 \sim 1.75$ (0.25 刻み) の場合の変位 応答を弾性固有周期 $T=0.05 \sim 1.0$ 秒 (0.05 秒刻み) の範囲で， 64 波の地震波を最大加速度 $980 \mathrm{gal}$ で規準 化してそれぞれの地震波に対して中点加速度法で求め た。减衰は, 瞬間剛性に対する内部粘性減衰とし, 减衰 定数は $2 \%$ とした。

ところで入力地震動の違いによる応答性状の差異を取 り除くために入力地震動をスペクトル強度 ${ }^{10)}$, 速度応答 値 ${ }^{12)}$ あいは弾性限入力加速度 ${ }^{11}$ 等で規準化した方が最 大加速度で規準化した場合よりその応答のばらつきが小 さくなるといわれている。しかし，本研究では多数の地 震波に対する最大值応答の絶対量を設計対象とするこ と，および取り扱う骨組が中低層 RC 骨組であること を考虑して簡単のための文献 9) と同様, 地震波を最大 加速度で規準化して解析を行った。

\subsection{4 $S_{D p}(T)$ の $S_{D e}(T)$ からの推定式}

$S_{D p}(T)$ は D-Tri 応答より得られる変位応答值の最大 值を包絡する曲線を， $k_{y} / k_{g}$ および $T$ を変数として $S_{D e}(T)$ をもとに推定する。推定には, Newmark が 1 質 点完全弾塑性系で定義したエネルギー一定則 ${ }^{8)}$ を拡大解 釈して, D-Tri 応答が塑性率 $\mu$ があまり大きくない範囲 で完全弾塑性応答に等しいと仮定する。この仮定のもと に図一17に示す系の初期剛性および降伏点剛性を用い て次式に示す形のエネルギー一定式における係数 $C$ を 変化させることにより D-Tri 応答を弾性応答より推定 する。

\section{1) 初期剛性をもとに推定する場合}

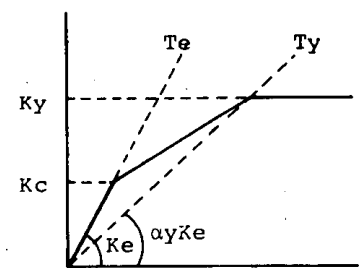

図-16初期㴊性と降伏点 剛性との関係

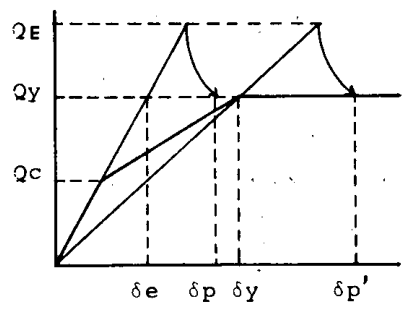

図一17初期剛性および降伏点 剛性を基にした推定法

$$
Q_{y} / Q_{E}\left(T_{e}\right)=C / \sqrt{2 \mu-1}
$$

2）降伏点剛性をもとに推定する場合

$$
Q_{y} / Q_{E}\left(T_{y}\right)=C / \sqrt{2 \mu^{\prime}-1}
$$

ここに $Q_{E}\left(T_{e}\right), Q_{E}\left(T_{y}\right): T_{e}, T_{y}$ に対応する弾性応答せ ん断力, $Q_{y}$ : 降伏せん断力, $\mu, \mu^{\prime}$ : 初期および降伏点 剛性に対応する塑性率 $\left(\mu=\delta_{p} / \delta_{e}, \mu^{\prime}=\delta_{p}^{\prime} / \delta_{y}, \delta_{p}, \delta_{p}^{\prime}\right.$ : 推定応答値)

以上の仮定のもとに 64 波の地震波に対する D-Tri 応 答を包絡する曲線を弾性応答より推定する式として次式 を得た。なお, 以下に示す式は, 多質点系の D-Tri 応 答においても弾性および塑性範囲でも 1 次モードが卓越 すると仮定して多質点系を 1 質点系に縮約した換算値 ${ }^{21)}$ を用いて表示し，その場合は添字〜を付した。

D-Tri 応答の最大值が系の降伏変位 $\tilde{\delta}_{y}$ 以下となる下 限の弾性固有周期 $T_{e q}$ を次式により求める。

$$
T_{e q}=1.6-\tilde{k}_{y} / k_{g}
$$

1) $T \geq T_{e q}$ の時

$$
S_{D p}(T)=\max \left\{\delta_{p}(T), \delta_{D e}(T)\right\}
$$

2) $\sqrt{\alpha_{y}} \cdot T_{e q} \leq T<T_{e q}$ の時

$$
S_{D_{p}}(T)=\sqrt{T_{e q} / T} \cdot \delta_{p}(T)
$$

3) $T<\sqrt{\alpha_{y}} \cdot T_{e q}$ の時

$$
S_{D p}(T)=\min \left\{\delta_{p}^{\prime}(T), \frac{1}{\sqrt[4]{\alpha_{y}}} \delta_{p}\left(\sqrt{\alpha_{y}} \cdot T_{e q}\right)\right\}
$$

ここに

$$
\begin{aligned}
& \delta_{p}(T)=\frac{1}{2}\left\{\left(\frac{Q_{E}\left(T_{e}\right) \cdot c}{\tilde{Q}_{y}}\right)^{2}+1\right\} \tilde{\delta}_{e}(T) \\
& \delta_{p}^{\prime}(T)=\frac{1}{2}\left\{\left(\frac{\tilde{Q}_{E}\left(T_{y}\right) \cdot c}{\tilde{Q}_{y}}\right)^{2}+1\right\} \tilde{\delta}_{y}(T) \\
& c=1.0 \quad(T \leq 0.35 \mathrm{sec} \text { の時） } \\
& =1.14-0.4 T \quad(0.35<T \leq 0.6 \mathrm{sec} \text { の時 }) \\
& =0.9 \\
& \text { ( } T>0.6 \sec \text { の時) } \\
& \tilde{\delta}_{e}(T)=\tilde{Q}_{y} / \tilde{K}_{e}(T) \quad \tilde{\delta}_{y}(T)=\tilde{Q}_{y} /\left(\alpha_{y} \cdot \tilde{K}_{e}(T)\right) \\
& \tilde{K}_{e}(T)=(2 \pi / T)^{2} \tilde{m} \quad \tilde{Q}_{E}(T)=\tilde{K}_{e}(T) \cdot \delta_{D e}(T) \\
& \tilde{m}=\sum_{i=1}^{N} m_{i} \phi_{i}^{(1)} \quad \tilde{Q}_{y}=\sum_{i=1}^{N} Q_{y i}\left(\phi_{i}^{(1)}-\phi_{i-1}^{(1)}\right) \\
& \tilde{k}_{y}=\tilde{Q}_{y} /(\tilde{m} \cdot g) \\
& \alpha_{y}=\frac{\sum_{i=1}^{N} K_{y t}\left(\phi_{i}^{(1)}-\phi_{i-1}^{(1)}\right)^{2}}{\sum_{i=1}^{N} K_{e i}\left(\phi_{i}^{(1)}-\phi_{t-1}^{(1)}\right)^{2}}
\end{aligned}
$$

$$
\begin{array}{rlrl}
T_{y}=T_{e} / \sqrt{\alpha_{y}} & & \\
\delta_{D e}(T) & =90 T^{2} k_{g}[\mathrm{~cm}] & & (T \leq 0.6 \mathrm{sec} \text { の時 }) \\
& =54 T k_{g} \quad[\mathrm{~cm}] & & (T>0.6 \mathrm{sec} \text { の時 })
\end{array}
$$

$K_{e i}, K_{y i}: i$ 層弾性および降伏点剛性， $m$ : 質量 なお，(28）式右辺第 2 項は $\delta_{p}(T)$ と $\delta_{\rho}^{\prime}(T)$ との不連 続をなくすために便宜的に引いた直線である。

図一18は， $S_{D p}(T)$ 推定のルールを模式的に示したも のである。図一19〜図-21は提案した推定式とD-Tri 応答との関係を 1 質点系について示したもので $m=1$, 
$k_{g}=1.0$ とした時の $k_{y} / k_{g}=1: 0,1.25,1.5$ および $\alpha_{y}$ $=0.25,0.50$ の場合について示した。図より $\alpha_{y}=0.5$ の場合の応答値は, $T=0.2$ および 0.8 秒前後で応答值
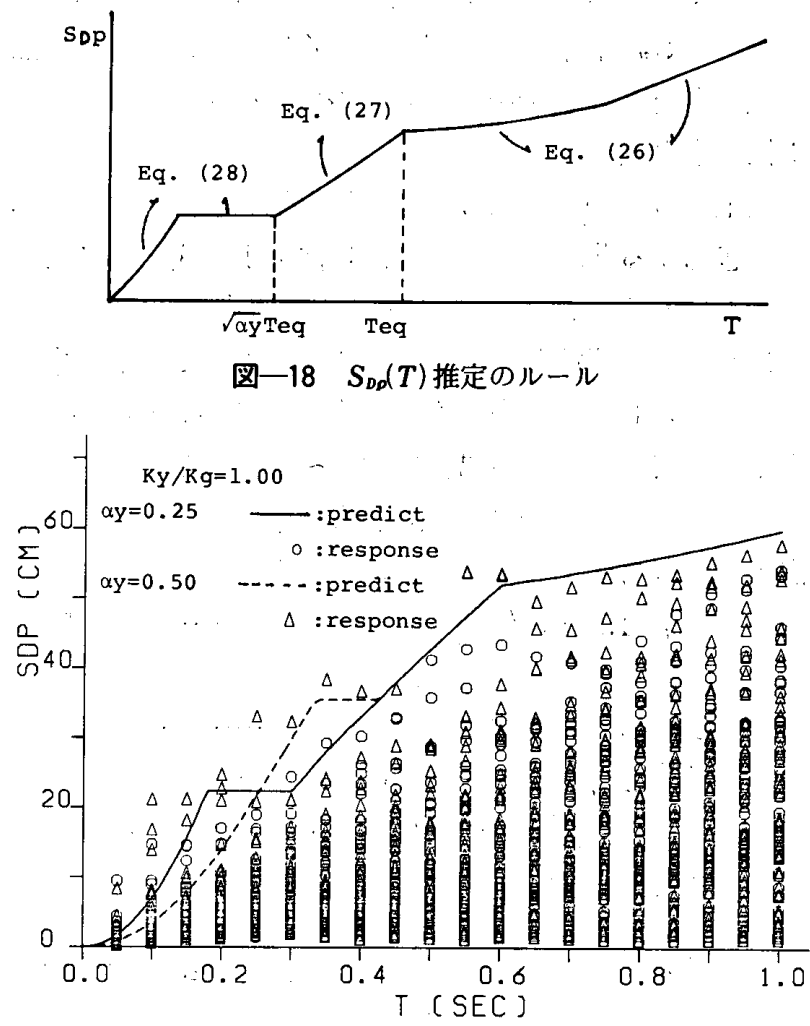

図一19 推定式と D-Tri 応答值との関係

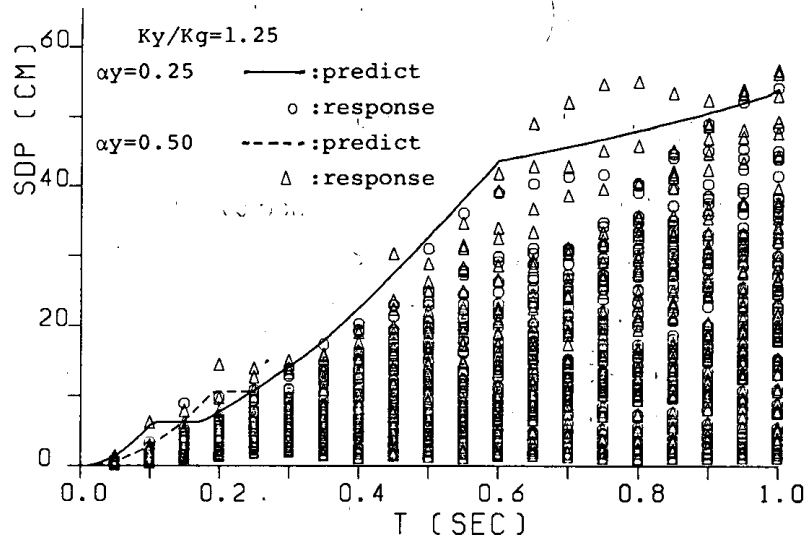

図一20 推定式と D.Tri 応答値との関係

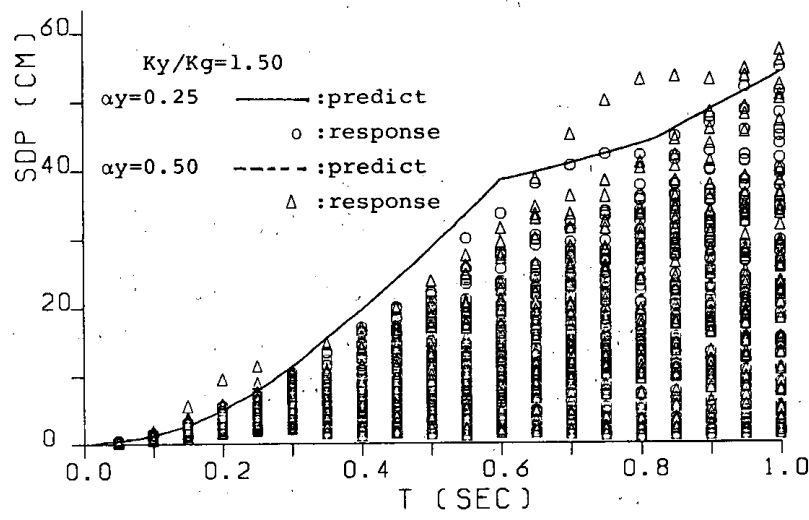

图一21 推定式とD-Tri 応答值との関係
表一 9 最大変位応答値と推定値との関係

\begin{tabular}{|c|c|c|c|c|c|c|}
\hline & story No. & 1 & 2 & 3 & 4 & 5 \\
\hline \multirow{2}{*}{ Case 1} & $\delta p i$ (predict) & 3.63 & 3.96 & 4.15 & 3.65 & 3.17 \\
\hline & spi (actual) & 3.89 & 3.98 & 4.24 & 3.57 & 1.90 \\
\hline \multirow[b]{2}{*}{ Case 2} & $\delta p i$ (predict) & 5.00 & 4.89 & 3.61 & & \\
\hline & $\delta$ pi (actual) & 4.99 & 5.52 & 2.38 & & $(\mathrm{~cm})$ \\
\hline
\end{tabular}

が推定值を上回る場合がある。一方; $\alpha_{y}=0.25$ の場合 は応答值が $k_{y} / k_{g}=1.0$ の時, 推定值が短周期において 下回る場合を除いて, 推定式はほぼ応答值の最大値を包 絡する曲線となっている。3 章で示した設計骨組の $\dot{\alpha}_{y}$ の值が 0.25 前後であったことを考えると，本研究で取 り扱った RC 平面ラーメンに限れば推定式により D-Tri 応答の最大值をほぼ推定できるものと思われる。

表一9.に，3 章に示したCase 1; Case 2 の設計骨組に， $k_{g}=0.3$ で規準化した 64 波の地震波を適用して SB モ デルで求めた変位応答の最大值と，(21）式において. $f$ $=3$ とした時の推定値との関係を示す。表一 9 より骨組 各層のひびわれおよび降伏変位 $\delta_{c}, \delta_{y}$ がほぼ一様で骨 組が同時降伏する Case 1 の場合は，最上階を除いて推 定式によりほぼ変位応答の最大值を予測できることがわ かる。一方，一部の層の風性が他の層に比べて弱いよう なCase 2 の骨組の場合は, 弱い層に変形が集中するた め,その層に関する推定值はやや低目の値亡なっている。 いずれにしても, 塑性変形モード:弾性変形モードがほ ぼ比例するように骨組を設計すれば推定式により応答の 最大值を予測できるといえる。そのような設計法につい ては次節で示す。

4.3 地震時塑性層間変位を一様化する $\mathrm{RC}$ 骨組の設 計

ここでは，次式に示すように与えられた地動の最大震 度に対して骨組各層の塑性層間変位 $\delta_{\rho i}$ が指定した許容 塑性層間変位 $\delta_{p a}$ に等しくする設計を考える。

$$
\delta_{p i}=\delta_{p a} \quad(i=1, \cdots, N)
$$

D-Tri 型復元力特性をもつ RC 骨組の $\delta_{\rho t}$ は, 図一19 一図一21にみられるように層の保有水平耐力 $Q_{y}$ および 弾性固有周期 $T$ により大きく影響される。本研究では, このうち $T$ の值, すなわち骨組の弾性層剛性分布を制 御することにより $(30)$ 式を満す $\mathrm{RC}$ 骨組の設計を行う。 これは， $Q_{y}$ で制御すると， $k_{y} / k_{g}$ の值がある゙值を超え ると変位応答値がほぼ一定となる場合があり $Q_{\boldsymbol{y}}$ を制御 するだけでは (30) 式を満す設計が困難となることがあ るためである。そのため, 設計では保有水平耐力分布は 固定して，(30) 式の制約条件のもとで骨組総重量を最 小にする弾性層剛性 $K_{i}$ の分布を既報 ${ }^{2)}$ に示した方法よ り求め, 得られた $K_{i}$ の分布に対応するよう設計解を求 めるこ亡亡し，以下の繰り返し手順により解析を行う。 なお, $\cdots(21)$ 式により $\delta_{p i}$ を算定すると最上階の層剛性 がやや過大評価されることになるが，骨組全体の重量変 
化からみるとその影響は小さいとして，この点は設計で は考慮しないものとする。

1） 3 章で示した方法による RC 骨組設計解より各層 のはりせい $h_{b i}$, 柱せい $D_{i}$ を求め, 地震時層重量 $W_{i}$, 保有水平耐力 $Q_{y i}$ および $D$ 值法より弾性層剛性 $K_{i}$ を求 める。なお， $W_{i}, Q_{y t}$ の値は 10）の手順まで固定する。

2） $K_{i}$ を用いて固有值解析を行い, (21)式より $\delta_{p i}$ を, 次式により $\delta_{p i}$ に対応する層せん断力 $Q_{p i}$ を求める。

$$
\begin{array}{r}
Q_{p t}=\sqrt{\sum_{k=1}^{f}\left(\Omega_{k} \beta_{k} S_{D p}\left(T_{k}\right) \sum_{j=i}^{N} m_{j} \phi_{j}^{(k)}\right)^{2}} \\
(i=1, \cdots, N) \cdots \cdots \cdots
\end{array}
$$

ここに $\Omega_{k}: k$ 次弾性固有値

3）（30）式の検定を行い, 満足すれば11）へ行く。

4） $Q_{p i}$ が骨組に静的に作用した時, 各層の弾性層間 変位が一様化する設計解を, 既報 ${ }^{21}$ の $2.4,2.5$ 節に示 した層間変位制限を受ける $\mathrm{RC}$ 骨組の最小重量設計法 より求め, 設計解に対応する弾性層剛性 $K_{i}^{* 1}$ を求める。 この時, 指定する層間変位の值は $\delta_{p l}$ の平均値とする。

5）既報”に示したように $K_{i}^{* 1}$ は近似解であるため, $Q_{p i}$ に対して $K_{i}^{* 1}$ は各層わずかに異なった弾性層間変位 を与えるため, 次式により $K_{l}^{* 1}$ を $K_{l}^{* 2}$ に変更し， $Q_{p t}$ に対する層間変位を一様化する。

$$
K_{i}^{* 2}=Q_{p i} / \bar{\delta}^{* 1} \quad(i=1, \cdots, N)
$$

$$
\text { ここに } \bar{\delta}^{* 1}=\text { aver. } \delta_{i}^{* 1}, \delta_{i}^{* 1}=Q_{p t} / K_{i}^{* 1}
$$

6） $K_{i}^{* 2}$ を用いて固有值解析を行い， 1 次固有周期に ついて $T_{1}^{* 2} \neq T_{1}$ なら次式により $K_{i}^{* 2}$ を $K_{l}^{* 3}$ に変更し, $K_{i}^{* 3}$ を用いて 2) と同様の方法により $\delta_{p i}, Q_{p i}$ を求める。 ここで $T_{1}$ は2）の手順で求めた弾性 1 次固有周期であ る。

$$
K_{l}^{* 3}=K_{i}^{* 2}\left(T_{1}^{* 2} / T_{1}\right)^{2}
$$

7） $\delta_{p i}$ の一様化を検定し，一样化していない場合は 2）に戻り，与えられた $T_{1}$ に対して $\delta_{p l}$ が一様化するま で計算を繰り返す。

8） $\delta_{p t}$ が一様化した場合は次式により収束判定を行 う。

$$
\left|\delta_{p t}-\delta_{p a}\right|<\varepsilon,(i=1, \cdots, N) \cdots
$$

9）（34）式を満足しない場合は, 次式により次ステッ プのための固有周期 $T$ 小ならびに $K_{i}$ を求め，2）に戻る。

$$
\begin{aligned}
& T_{J}=T_{J}^{* 3} \cdot \delta_{p a} / \text { aver } . \delta_{p i} \quad(j=1, \cdots, f) \cdots(35 \cdot \mathrm{a}) \\
& K_{i}=K_{i}^{* 3}\left(T_{1} / T_{1}^{* 3}\right)^{2} \quad(i=1, \cdots, N) \cdots \cdots \cdots(35 \cdot \mathrm{b})
\end{aligned}
$$

10）収束した場合は $K_{i}^{* 3}$ に対応するよう部材寸法を 変更する。本研究では保有水平耐力 $Q_{y}$ の値を変更しな い条件より，はりせい $h_{b t}$ をそのままにして，各層の柱 せいを変更することにより改修設計解とする。改修柱せ い $D_{i}$ は, $D$ 值法による首剛性算定式を用いて求め, 改 修した $D_{i}$ が 1) で定めた $D_{t}$ より小さければ改修 $D_{i}$ を 1）で定めた $D_{i}$ とする。

11）改修設計解に対して，3 章で示した 1 次および 2
次設計を行って $W_{i}, Q_{y i}, T$ を求めた後，2）に戻り同 様の計算を改修設計解が収束するまで繰り返す。

\section{4 解析例およびその考察}

3 章に示した設計骨組を用いて, 地動の最大震度を $k_{g}=0.3$ および $\delta_{p a}=h_{t} / 100$ とした時の設計例を示す。 なお解析では, 骨組の降伏点剛性低下率 $\alpha_{y}$ の值は, 3 章の解析例より判断して $\alpha_{y}=0.25$ と固定し, 考慮した

\begin{tabular}{|c|c|c|c|c|c|c|}
\hline \\
\hline \multirow{7}{*}{ Case 1} & story No. & 1 & 2 & 3 & 4 & 5 \\
\hline & $K i(t f / c m)$ & $\begin{array}{l}127.0 \\
137.8 \\
\end{array}$ & $\begin{array}{l}106.3 \\
125.2 \\
\end{array}$ & $\begin{array}{r}85.1 \\
106.3 \\
\end{array}$ & $\begin{array}{l}72.8 \\
79.9 \\
\end{array}$ & $\begin{array}{l}49 . \overline{8} \\
49.8\end{array}$ \\
\hline & $\mathrm{Di}(\mathrm{cm})$ & $\begin{array}{l}55.0 \\
56.6 \\
\end{array}$ & $\begin{array}{l}54.3 \\
58.1 \\
\end{array}$ & $\begin{array}{l}50.7 \\
55.4 \\
\end{array}$ & $\begin{array}{l}50.1 \\
52.1\end{array}$ & $\begin{array}{l}46.7 \\
46.7 \\
\end{array}$ \\
\hline & $\mathrm{hbi}(\mathrm{cm})$ & 79.9 & $\begin{array}{l}84.4 \\
11\end{array}$ & 76.3 & 70.1 & 56.0 \\
\hline & $\phi i^{(1)}$ & $\begin{array}{l}0.476 \\
0.500 \\
\end{array}$ & $\begin{array}{l}1.005 \\
1.009 \\
\end{array}$ & $\begin{array}{l}1.564 \\
1.516 \\
\end{array}$ & $\begin{array}{l}2.040 \\
2.008\end{array}$ & $\begin{array}{l}2.408 \\
2.439 \\
\end{array}$ \\
\hline & $\phi i^{(2)}$ & $\begin{array}{l}-1.182 \\
-1.137\end{array}$ & $\begin{array}{l}-1.951 \\
-1.840\end{array}$ & $\begin{array}{l}-1.609 \\
-1.630\end{array}$ & $\begin{array}{l}-0.033 \\
-0.167\end{array}$ & \\
\hline & $\phi i^{(3)}$ & $\begin{array}{l}-1.651 \\
-1.615 \\
\end{array}$ & $\begin{array}{l}-1.492 \\
-1.486 \\
\end{array}$ & $\begin{array}{l}1.048 \\
0.717 \\
\end{array}$ & $\begin{array}{l}2.160 \\
2.372 \\
\end{array}$ & $\begin{array}{l}-1.576 \\
-1.468\end{array}$ \\
\hline \multirow{6}{*}{ Case 2} & $K i(t f / c m)$ & $\begin{array}{l}64.3 \\
99.9 \\
\end{array}$ & $\begin{array}{l}52.7 \\
81.6 \\
\end{array}$ & $\begin{array}{l}46.1 \\
53.7 \\
\end{array}$ & \multirow{6}{*}{ 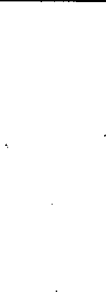 } & \\
\hline & $\mathrm{Di}(\mathrm{cm})$ & $\begin{array}{l}46.7 \\
54.4 \\
\end{array}$ & $\begin{array}{l}46.7 \\
58.8 \\
\end{array}$ & $\begin{array}{r}46.7 \\
50.5 \\
\end{array}$ & & \\
\hline & $\mathrm{hbi}(\mathrm{cm})$ & 65.3 & 64.3 & 55.9 & & \\
\hline & $\phi i^{(1)}$ & $\begin{array}{l}1.085 \\
1.009\end{array}$ & $\begin{array}{l}2.168 \\
2.029\end{array}$ & \multirow{3}{*}{$\begin{array}{l}2.866 \\
2.922 \\
2.241 \\
2.234 \\
0.998 \\
0.678\end{array}$} & & \\
\hline & $\phi \mathrm{i}^{(2)}$ & $\begin{array}{l}-2.502 \\
-2.151\end{array}$ & $\begin{array}{l}-1.618 \\
-1.960\end{array}$ & & & \\
\hline & $\phi i^{(3)}$ & $\begin{array}{l}2.484 \\
2.740\end{array}$ & $\begin{array}{l}-2.581 \\
-2.286\end{array}$ & & & \\
\hline
\end{tabular}
次数は $f=3$ とした。表一 10 に解析結果のうち， $K_{i}$, $D_{l}, h_{b t}$ および 3 次までの弾性固有モード $\phi_{t}$ の值を，そ れぞれの Case について tf・cm の単位で示す。表一11,

\begin{tabular}{|c|c|c|c|c|c|c|c|}
\hline $\begin{array}{c}\text { story } \\
\text { No. }\end{array}$ & $\begin{array}{c}\delta \mathrm{c} \\
(\mathrm{cm})\end{array}$ & $\begin{array}{l}Q C \\
(t f)\end{array}$ & $\begin{array}{c}\delta y \\
(\mathrm{~cm})\end{array}$ & $\begin{array}{c}Q y \\
(t f)\end{array}$ & $\begin{array}{c}\text { Wi } \\
\text { (tf). }\end{array}$ & $\begin{array}{l}Q 1 d \\
(t f) \\
\end{array}$ & $\begin{array}{l}Q 2 d \\
(t f) \\
\end{array}$ \\
\hline 1 & 0.37 & 51.6 & 2.88 & 113.4 & 80.0 & 75.6 & 113.4 \\
\hline 2 & 0.40 & 49.7 & 3.91 & 102.0 & 79.3 & 68.0 & 102.0 \\
\hline 3 & 0.39 & 41.8 & 3.78 & 85.8 & 76.9 & 57.2 & 85.8 \\
\hline 4 & 0.41 & 32.9 & 3.78 & 65.0 & 72.8 & 43.3 & 65.0 \\
\hline 5 & 0.42 & 21.2 & 3.58 & 45.1 & 68.9 & 26.3 & 39.4 \\
\hline
\end{tabular}
表一12 に改修骨組の復元力特性および $W_{t}, Q_{1 d}, Q_{2 d}, T$, の値を，それぞれの Caseについて示す。表一13に，64

\begin{tabular}{|c|c|c|c|c|c|c|c|}
\hline $\begin{array}{l}\text { story } \\
\text { No. }\end{array}$ & $\begin{array}{c}\delta \mathrm{c} \\
(\mathrm{cm}) .\end{array}$ & $\begin{array}{c}Q C \\
(t f)\end{array}$ & $\begin{array}{c}\delta y \\
(\mathrm{~cm}) \\
\end{array}$ & $\begin{array}{c}Q Y \\
(t f)\end{array}$ & $\begin{array}{c}w i \\
(t f)\end{array}$ & $\begin{array}{l}Q 1 d \\
(t f)\end{array}$ & $\begin{array}{l}Q 2 d \\
(t f)\end{array}$ \\
\hline 1 & 0.34 & 34.2 & 2.23 & 65.7 & 74.6 & 43.8 & 65.7 \\
\hline 2 & 0.38 & 30.9 & 3.24 & 52.5 & 74.5 & 35.0 & 52.5 \\
\hline 3 & 0.37 & 20.1 & 3.09 & 37.2 & 70.1 & 21.5 & 32.3 \\
\hline
\end{tabular}
波の実地震波に対するSB モデルによる変位応答の最大 值を, $k_{g}=0.3$ で規準化した場合の結果を示す。なお，

註）上段：改修前 下段：改修後

表一11 改修骨組の復元力特性, $W_{i}, Q_{1 d}, Q_{2 d}, T$ の値 (Case 1 )

表一12 改修骨組の復元力特性, $W_{i}, Q_{1 d}, Q_{2 d}, T$ の値 (Case 2)

表一13 改修前のおよび後の最大変位応答值

\begin{tabular}{l|c|ccccc}
\hline & story No. & 1 & 2 & 3 & 4 & 5 \\
\hline Case 1 & $\delta \mathrm{pi}, \max$ & 3.89 & 3.98 & 4.24 & 3.57 & 1.90 \\
& $(\mathrm{~cm})$ & 3.53 & 3.56 & 3.51 & 3.36 & 1.72 \\
\hline \multirow{2}{*}{2} & $\delta \mathrm{pi}, \max$ & 4.99 & 5.52 & 2.38 & & \\
& $(\mathrm{~cm})$ & 3.58 & 3.52 & 1.42 & & \\
\hline
\end{tabular}

註）上段：改修前 下段：改修後 
表一 10 , 表一 13 において上段の值は改修前骨組，下段 の値は改修後骨組に対する値を示す。

表一10 表一12 より, 改修された骨組の弾性層剛性 は，下層部において剛性が高められ，その割合は中間層 においてより大きくなっている。また, 弾性 1 次固有モ二 ドはほぼ直線形となり，この結果は弾性応答を扱った中 村らによる結果 ${ }^{5), 6)}$ とも一致する。改修された骨組の復 元力特性は， $\delta_{c}, \delta_{y}^{\prime}$ の值が各層ほぼ一様化し， 3 章で示 されたような特定の層の層剛性が弱くなるような設計の 改善がなされ，また改修による $Q_{y i}, W_{i}$ の増加はわずか であった。表一13より，改修骨組に対する応答の最大 値はほぼ指定した値となり，本方法による $\delta_{p t}$ を制御す る設計解は妥当な値を示していると言える。ただし，応 答の最大值が若干許容値より大きくなっているが，これ は $\delta_{p a}$ の值を数 \% 程度爰しくすることにより改善され るものと思われる。

\section{5. 結 語}

本研究の内容および解析例より得られた結果を要約す ると次のごとくなる。

1）最適設計理論を適用して新耐震設計法および日本 建築学会 $R C$ 構造計算規準に準拠する $\mathrm{RC}$ 骨組の最適 設計法を示した。設計は 1 次設計および 2 次設計につい て行った。その結果, 最終設計解决定には，2次設計で 用いた保有水平耐力条件およびはり，降伏形条件が重要な 役割を果すことが分った。また, 設計骨組は単調載荷弾 塑性解析によればほぼ同時降伏形の骨組として設計され るが，多数の実地震波による弾塑性応答解析によれば， 大地震時においで一部の地震波に対して変位応答の最大 值が大きくなり骨組の勒性確保が困難となることがあ る。

2） D-Tri 型復元力特性をもつ RC 骨組の地震時塑性 層間変位の最大值分布をモーダルアナリシス, RMS 法 および塑性変位応答スペクトルを用いて弾性応答より推 定する方法を，多数の実地震波に対する D-Tri 応答結 “果をもとに統計的に取り扱うことにより示した。提案し た方法は，解析に用いた実地震波に限れば同時降伏形の 骨組に対する変位応答の最大值分布を推定する場合に良 い近似を与える。

3）大地震時塑性層間変位の最大值分布を制御する設 計法を，すでに示した最適設計理論を用いて行う方法に ついて示した。設計では，塑性層間変位の最大値分布を 一様化するに必要な弾性層剛性分布を繰り返し計算によ り求める方法について示した。また，解析例を通して本 方法により塑性層間変位を一様化する設計解が精度良く 求まることを示した。

\section{参考文献}

1）小阪義夫, 今井信宏：鉄筋コンクリート骨組の最適設計
に関する研究（その 1 最適化計算法および多層多スパ ン骨組への適用)，日本建築学会論文報告集，第 290 号， pp. 23 33, 1980.4

2) 今井信宏：同上(その 2 最適化計算における初期設計 解の推定), 日本建築学会構造系論文報告集, 第 350 号, pp. 16 27, 1985.4

3）今井信宏：同上（その 3 ：動的応答を考慮した $R C$ 骨組 の設計)，日本建築学会構造系論文報告集，第 360 号， pp. 31 43, 1986:2

4）日本建築学会：鉄筋コンクリート構造計算規準, 同解説, 1982

5) 中村恒善, 山根尚志: 1 次固有周期制約条件下の最適設 計解とそれに基づく地震時応答変位の最大值の制御, 日 本建築学会大会梗概集 (北陸), pp. 1041 1042, 昭和 58.9

6) 中村恒善, 中村，豊：2 軸偏心せん断型構造物の 1 次固 有周期制約条件下の最適設計解に基づく地震時弾性応答 量の制御法, 日本建築学会大会梗概集 (東海), pp. 273 $\sim 274$, 昭和 60.10

7) S.W. Zagajeski and V.V. Bertero: Optimum SeismicResistant Design of R/C Frames, ASCE, Vol. 105, No.ST5, :pp. 829 845, May, 1979

8）金多梁訳：超高層鉄筋コンクリート建築の耐震設計，日 本セメント技術協会, 昭和 40 年

9) 芳村 学, 青山博之: Degrading Tri-linear Model を用 いた地震応答の弾性応答からの推定法（その1, その 2$)$ ， 日本建築学会関東支部研究報告集, pp. 29 32, 1975 お よび日本建築学会大会梗概集（関東），pp. 1063 1064, 昭和 50.10

10）関 崇夫, 西川孝夫：弾塑性応答計算に用いる地震動の 強さの評価に関する検討 (その 6 ), 日本建築学会大会梗 概集 (北海道); , pp. 663 664, 昭和 61.8

11）久保哲夫, 松本大司：強震時の $\mathrm{R} / \mathrm{C}$ 構造物の弾塑性応答 量の推定, 日本建築学会大会梗概集 (東海), pp. 25 26, 昭和 60.10

12）鈴木威祐, 島崎和司： $\mathrm{RC}$ 構造物の地震時水平変位量の 簡易な推定法について（その1, その2），日本建築学会 大会梗概集 (東海), pp. $21 \sim 24$, 昭和 60.10

13）滝沢春男, 関. 弘義：梁崩壊型 RC 骨組を実現する柱, 梁の耐力比, 日本建築学会大会梗概集 '(関東), pp. 2203 $\sim 2204$, 昭和 59.10

14）久保哲夫, 中瀬知幸：梁崩壊制御の靶性 $\mathrm{RC}$ 造建物の柱, 梁耐力比に関する基礎的研究 (その 1 , その 2$)$, 日本建 築学会大会梗概集 (北海道), pp. 695 698, 昭和 61.8

15），広沢雅也，山内博之：新しい酎震設計法に基づく建築物 の構造設計の実際, カラム, 第 82 号, pp. 18 19, 1981

16) B. L. Gunnin : Non-linear Analysis of Planar Frames, doctor of philosophy, univ, of Texas, Janua. 1970

17）青山博之, 逸見'徹：鉄筋コンクリート造骨組の強震応 答解析（その 10 曲げせん断系モデルの定数の決定法に ついて), 日本建築学会関東支部研究報告集, pp. 33 36, 1975

18）梅村 魁：鉄筋コンクリート建物の動的耐震設計法，技 報堂, pp. 105 120および pp. 280，昭和 48 年

19) World Data Center : Strong Motion Data from Japanese Earthquakes, Decem., 1981 
20）大崎順彦：地震動のスペクトル解析入門，鹿島出版会， 昭和 57 年
21） 日本建築学会：地震荷重と建築構造物の耐震性, pp. 14 および pp. 148 157, 1976

\section{SYNOPSIS}

UDC : 624. $02: 624.042 .7: 620.1$

\section{OPTIMAL DESIGN OF R/C FRAMES ACCORDING TO “SHIN-TAISHIN" DESIGN METHOD}

by NOBUHIRO IMAI, Research Assistant of Nagoya Univ., Member of A.I.J.

This paper describes an analytical method for the optimum design of R/C frames according to the "ShinTaishin" design metnod.

The design process are consist of two parts, that is, the strength design and the stiffness design of frames. In the strength design, allowable stress design method is applied for the cross-sectional design of each member, and first and second design of frames are carried out according to the "Shin Taishin" design method. In the stiffness design, the dynamic plastic relative story displacements are controled in optimization procedure and they are estimated based on the modal analysis, RMS method and the plastic displacement spectrum. The plastic displacement spectrum which consider responses by the degrading tri-linear model is predicted from the elastic displacement spectrum.

The minimum weight design of two types of $\mathrm{R} / \mathrm{C}$ frames are carried out by the proposed method, and the results are discussed. 